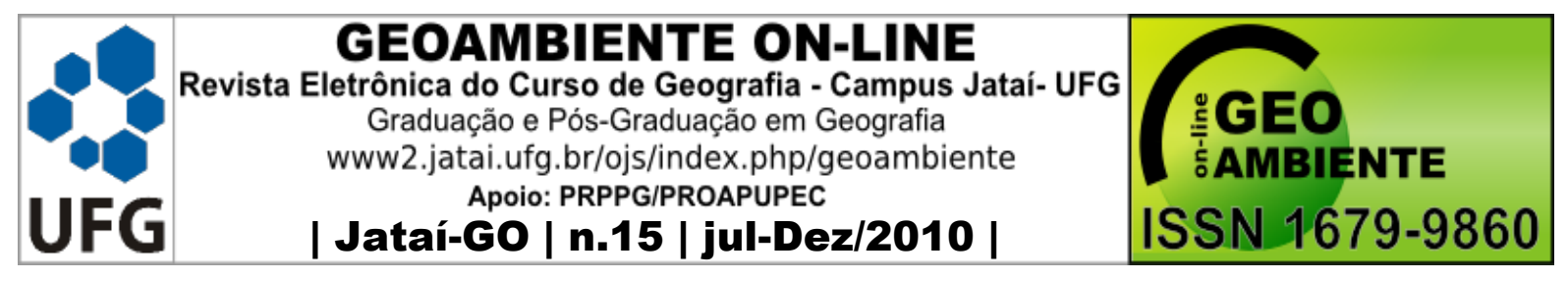

\title{
AVALIAÇÃO DOS EFEITOS DA OCUPAÇÃO URBANA NO ESCOAMENTO SUPERFICIAL NA MICROBACIA DO CÓRREGO MOGI E LAGOINHA EM UBERLÂNDIA - MG
}

\author{
João Mateus de Amorim ${ }^{1}$, Laerte Bernardes de Arruda $^{2}$ \\ ( 1 - Doutorando em geografia - UNESP de Rio Claro, joao_mateus2007@yahoo.com.br, 2 \\ Professor Aposentado da Engenharia Civil - UFU, lbarruda@gmail.com)
}

\section{Resumo}

Esta pesquisa avaliou o efeito da urbanização e a ocupação do solo na qualidade do escoamento superficial do córrego Mogi, em Uberlândia - MG, por meio da coleta de amostras de água obtidas no momento da chuva e em períodos secos. A coleta de amostras foi realizada na sarjeta do sistema de drenagem, na área de preservação permanente e em vários pontos do escoamento fluvial do córrego Mogi e do córrego Lagoinha. Os parâmetros analisados são: $\mathrm{pH}$, temperatura, demanda bioquímica de oxigênio (DBO), oxigênio dissolvido (OD), sólidos suspensos totais (SST), turbidez, cobre, ferro e zinco. O escoamento da sarjeta da área ocupada, quando comparado com o escoamento da sarjeta da área em processo de ocupação, mostrou efeitos negativos da ocupação urbana. O escoamento fluvial no córrego Mogi e no córrego Lagoinha diluiu os poluentes durante as chuvas analisadas e está em conformidade como os padrões de qualidades especificados na classe 3 da Resolução 357/05 do CONAMA. Com relação à comparação com os parâmetros da classe 2, alguns resultados estão levemente superiores, como DBO, cobre e ferro. O escoamento superficial da sarjeta ao passar pela vegetação da mata ciliar melhorou sensivelmente a qualidade da água.

Palavras-chave: Gestão ambiental urbana, qualidade dos córregos urbanos e vegetação ciliar.

\section{Abstract}

Artigo recebido para publicação em 15 de março de 2010

Artigo aprovado para publicação em 25 de Novembro de 2010 


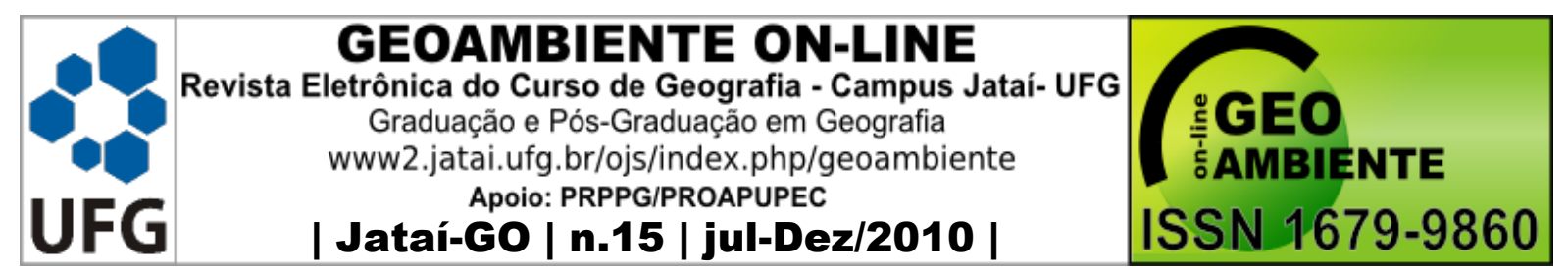

\section{THE EFFECTS OF URBANIZATION AND RUNOFF WATER QUALITY IN THE MOGI STREAM IN UBERLÂNDIA, MINAS GERAIS, BRAZIL}

The present study evaluated effects of the urbanization of a micro-basin and examined the quality of runoff water flowing into the Mogi stream in Uberlândia, MG. Samples of water were drawn during rainfall as well as the dry season. These samples were collected in the streams of water leading to the stream in areas of the land reserve as well as at various locations along the Mogi and Lagoinha stream. The data collected included: $\mathrm{pH}$, temperature, bio-chemical oxygen demands (BOD), dissolved oxygen (DO), total suspended solids (TSS), turbidity, copper, iron and zinc. The runoff of the occupied area, when compared with the drainage of the area in process of occupation demonstrated the negative effects of urban occupancy. Samples collected from the Mogi and Lagoinha stream show reduced levels of residues during the analyzed rains and it is in conformity as the patterns of qualities specified in the class 3 of the Resolution 357/05 of the CONAMA (Conselho Nacional do Meio Ambiente) index. The samples could not be considered to be of class 2 due to the results only slightly superior in terms of BOD, copper and iron, than found in the soils of the micro-basin. The passage of runoff water through the local vegetation of the ciliary's forest improved the quality of the water sensibly.

Keywords: urban environmental management, quality urban stream, ciliary's vegetation

\section{Resumen}

\section{EVALUACIÓN DE LOS EFECTOS DE LA OCUPACIÓN DE DESEMPATE} URBANO EN LA CUENCA DEL ARROYO Y LAGOINHA MOGI EN UBERLÂNDIA - MG

Esta investigación evaluó los efectos de la urbanización y el uso de la tierra en la calidad del flujo de escorrentía Mogi, Uberlândia - MG, mediante la recopilación de muestras de agua obtenidas en el momento de los períodos de lluvia y seca. El muestreo se llevó a cabo en el sistema de drenaje de alcantarillas en el área de conservación y en varios puntos de la corriente del caudal del río Mogi y corriente Pond. Los parámetros analizados son los 


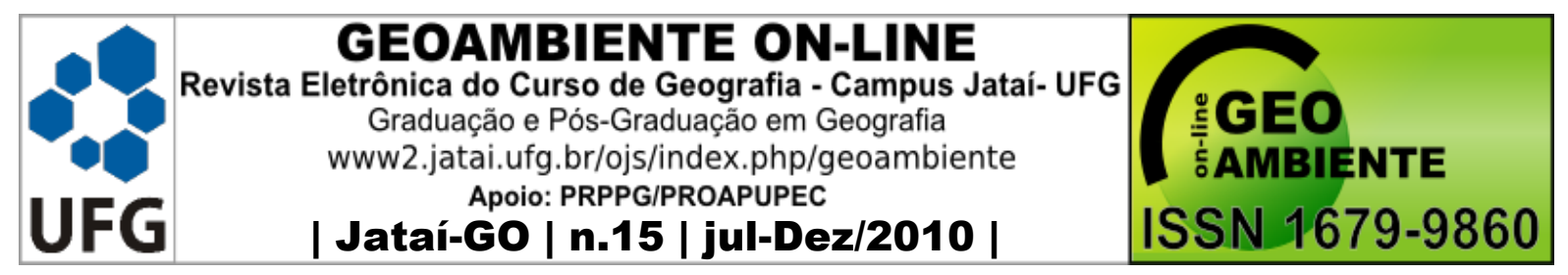

siguientes: $\mathrm{pH}$, temperatura, demanda bioquímica de la oxígeno (DBO) y el oxígeno disuelto (OD), sólidos suspendidos totales (SST), la turbidez, cobre, hierro y zinc. El escurrimiento de la alcantarilla de la zona ocupada en comparación con la segunda vuelta barranco área en el proceso de ocupación, mostraron efectos negativos de la ocupación urbana. El flujo en el río y el arroyo en arroyo estanque Mogi diluye los contaminantes durante las lluvias y se analizaron conforme a los estándares de calidad especificados en la clase 3 de la Resolución 357/05 de la CONAMA. La comparación con los parámetros de la clase 2, algunos resultados son ligeramente superiores, como DBO, cobre y hierro. El escurrimiento de la alcantarilla para pasar a través de la vegetación ribereña mejorado sustancialmente la calidad del agua.

Palabras clave: gestión del medio ambiente urbano, la calidad urbana de los arroyos y vegetación ribereña.

\section{1 - Introdução}

A expansão urbana no Brasil tem sido fruto de uma concentração populacional desordenada, sem planejamento, sem o Estudo de Impacto Ambiental (EIA) e sem o Relatório de Impacto Ambiental (RIMA) até a década de 1980. A partir desse período, surgiu a Lei Federal 6.938/81 (BRASIL, 1981), a Resolução 001 do Conselho Nacional de Meio Ambiente - CONAMA - (BRASIL, 1986) e a Constituição Federal de 1988 (BRASIL, 1988) que foi o marco das mudanças na questão ambiental no Brasil, em relação à ocupação urbana por loteamentos e equipamentos industriais nas proximidades de corpos hídricos.

O estudo da questão urbana, com ênfase no meio ambiente, deve ter uma visão que contemple todos os aspectos do cotidiano: sociais, ambientais, culturais, políticos e econômicos. Para a minimização dos impactos no escoamento das águas pluviais urbanas são necessários planejamento e gestão da drenagem superficial que, frente ao conhecimento das suas causas e seus efeitos, contemplem medidas estruturais (obras de infra-estruturas) e não estruturais (planejamento ambiental, educação ambiental, gestão ambiental) entre outros

A microbacia do córrego Mogi está sendo alterada pelo capital imobiliário e pelo processo de urbanização. Nesse contexto, fica claro que o artificial, o asfalto, as árvores 


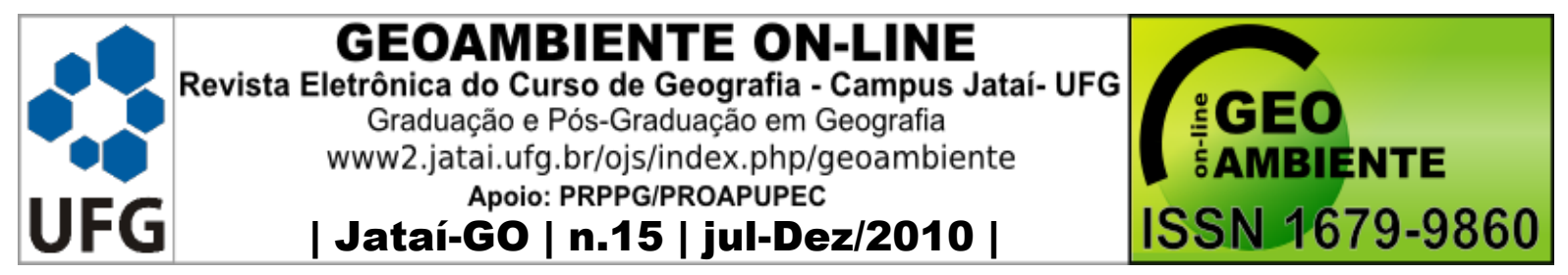

plantadas artificialmente invadiram o espaço do natural, da vegetação de Cerrado. Para o espaço urbano é necessária a conservação de áreas de preservação, como a vegetação ciliar, pois se espera que estas contribuam para a melhoria na qualidade da água por meio da retenção de sedimentos e resíduos do escoamento superficial urbano.

O objetivo deste artigo é compreender o efeito da urbanização e da ocupação urbana na qualidade do escoamento superficial direto em uma microbacia urbana e analisar os benefícios ambientais da cobertura vegetal na minimização do carreamento dos resíduos e sedimentos.

A justificativa deste trabalho está amparada em fatos e questões ambientais que prejudicam a qualidade de vida das populações urbanas. A qualidade de vida depende de um ambiente urbano mais limpo, arborizado, que propicie cidadania, lazer, esporte, cultura e educação. Assim, uma condição positiva para esse processo seria o planejamento ambiental urbano definindo políticas públicas apoiadas na democracia, na cidadania e na participação popular.

\section{2 - Metodologia}

Na microbacia do córrego Mogi, parte está urbanizada e ocupada, parte preservada com a cobertura vegetal do fundo de vale (APP) e parte preservada com o cerrado. A microbacia tem, atualmente, $70 \%$ de área preservada e 30\% de área urbanizada. Algumas pesquisas mostram que as porcentagens de espaços verdes superiores a 25\%, tornam-se eficientes para a minimização de diversos impactos ambientais, principalmente, daqueles relacionados às enchentes urbanas (TUCCI, 2005; JUSTINO, 2004).

Para verificar a qualidade da água foram definidos os seguintes parâmetros: potencial hidrogeniônico $(\mathrm{pH})$, demanda bioquímica de oxigênio (DBO), oxigênio dissolvido (OD), temperatura, turbidez, sólidos suspensos totais (SST) e concentrações de zinco (Zn), cobre $(\mathrm{Cu})$ e ferro $(\mathrm{Fe})$. As análises foram realizadas no período de verão e inverno do ano de 2008. 


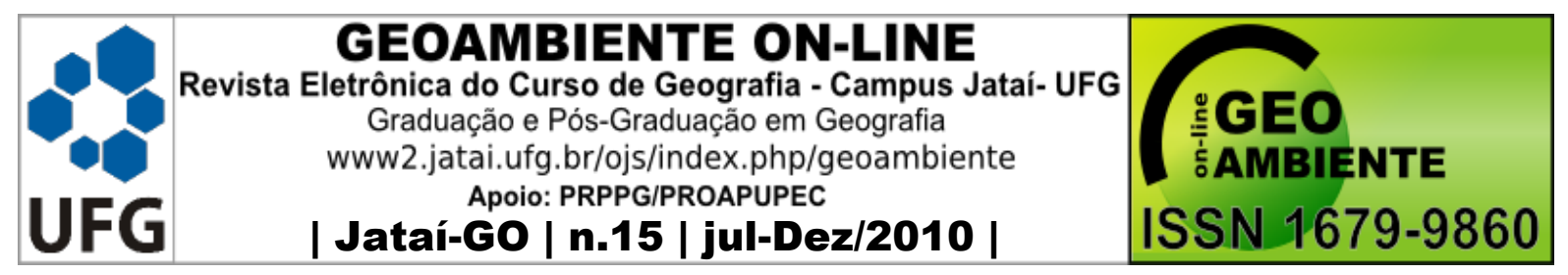

Os resultados dos dados obtidos em campo e em laboratório da BIOAGRI, da UFU e do SESI, com equipamentos de bancada, foram comparados com os parâmetros de qualidades da classe 2 e 3 estabelecidos pela Resolução 357/05 do CONAMA (BRASIL, 2005), apresentado na Tabela 1.

Tabela 1 - Parâmetros das classes 2 e 3 da Resolução 357/05.

\begin{tabular}{c|c|c|c|c|c|c|c|c|c}
\hline Dados & pH & Turbide & DBO & Zinco & Cobr & Ferr & OD & Temp. & SST \\
\hline Classe 2 & $6,00-$ & 100,00 & 5,00 & 0,18 & 0,00 & 0,3 & 5,00 & 40 & 500,00 \\
\hline Classe 3 & $6,00-$ & 100,00 & 10,00 & 5,00 & 0,01 & 5,00 & 4,00 & 40 & 500,00 \\
\hline
\end{tabular}

Fontes: Brasil, 2005

Para a realização da análise comparativa, com relação aos dados de $\mathrm{pH}$ das classes 2 e 3 da Resolução 357/05 (BRASIL, 2005), foi considerado a faixa de 6 e 9; para o OD os valores são os mínimos permitidos, já para o restante dos dados foram considerados os valores máximos preconizados.

A caracterização granulométrica do solo foi realizada com coleta de dois tipos de amostras, sendo a primeira o solo do cerrado e a segunda o solo carreado pelo escoamento pluvial, ou seja, os sedimentos acumulados no fim da área de descarga das águas pluviais urbanas. As amostras em destaque foram retiradas com o uso de uma enxada e transportadas para o laboratório da FECIV-UFU em sacos plásticos contendo cerca de $2 \mathrm{~kg}$ cada. Após a secagem foi realizada a análise granulométrica do solo, por peneiramento e pelo método de sedimentação ou pipetagem, pelo método (ABNT, 1984). Também foi realizada a análise para a determinação da concentração de cobre, zinco e ferro. Para esta análise foi realizada uma coleta na camada mais superficial do solo, devido às maiores possiblidades de arraste destes elementos nestas profundidades via erosão. A metodologia de análise do sedimento foi o Inductively Coupled Plasma (ICP) Method (USEPA, 1996) executada pela Bioagri Ambiental.

O levantamento e caracterização da área física experimental, onde foi coletado o escoamento superficial direto, foi realizado com a utilização de: teodolito, nível, bússola e 


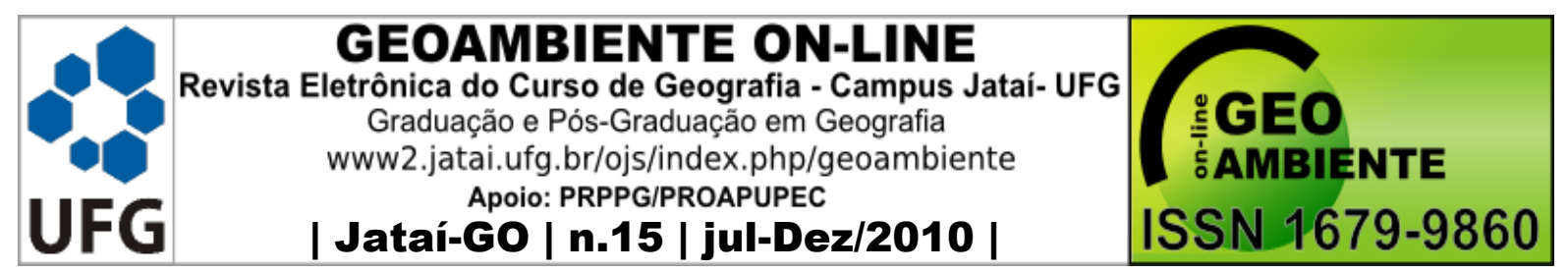

GPS. Também foi implantada na margem esquerda do córrego Mogi um pluviômetro para medir, no local, a altura precipitada. A instalação deste se deu em local distante de árvores e casas e altura de 1,50 m do solo.

Os ensaios de qualidade da água foram realizados pelo laboratório do Instituto de Química da Universidade Federal de Uberlândia (UFU), pelo laboratório de meio ambiente do Serviço Nacional de Aprendizagem Industrial (SENAI) e pelo laboratório Bioagri Ambiental (empresa particular).

\section{Descrição dos pontos de coleta}

Foram estabelecidos 7 pontos de coletas, mostrados na Figura 1 e descritos a seguir. Os pontos designados com letras são pontos nos córregos Mogi e Lagoinha e os designados com números são pontos de coleta do escoamento superficial (runnoff) sobre os terrenos da bacia.

- Ponto A: área de afloramento do lençol freático do córrego Mogi;

- Ponto B: córrego Mogi a jusante dos pontos A, I e II, no bueiro sob a Alameda Padre Manoel da Costa;

- Ponto C: no córrego Mogi a jusante do ponto A;

- Ponto D: córrego Lagoinha a jusante do ponto de deságüe do córrego Mogi;

- Ponto I: deságüe de uma rede de drenagem pluvial;

- Ponto II: na APP próximo ao córrego Mogi;

- Ponto III: córrego Lagoinha a montante do ponto F, no deságüe do escoamento superficial urbano (sarjeta) oriundo do Bairro Vigilato Pereira e outros. 


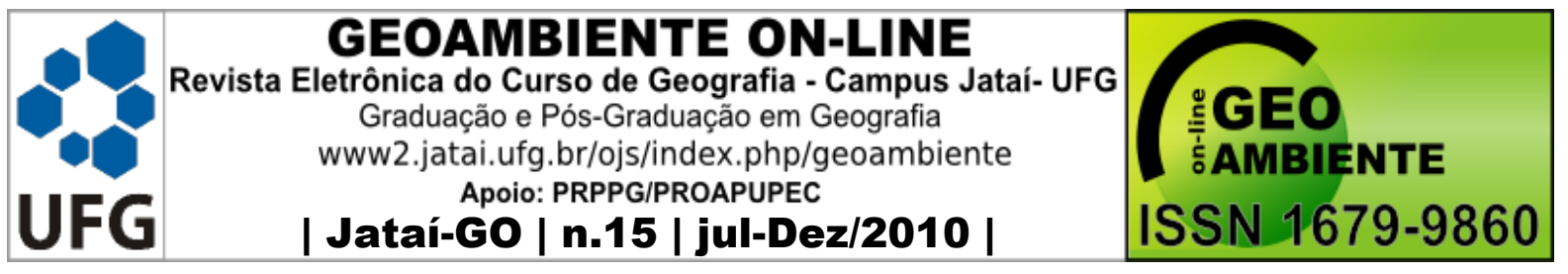

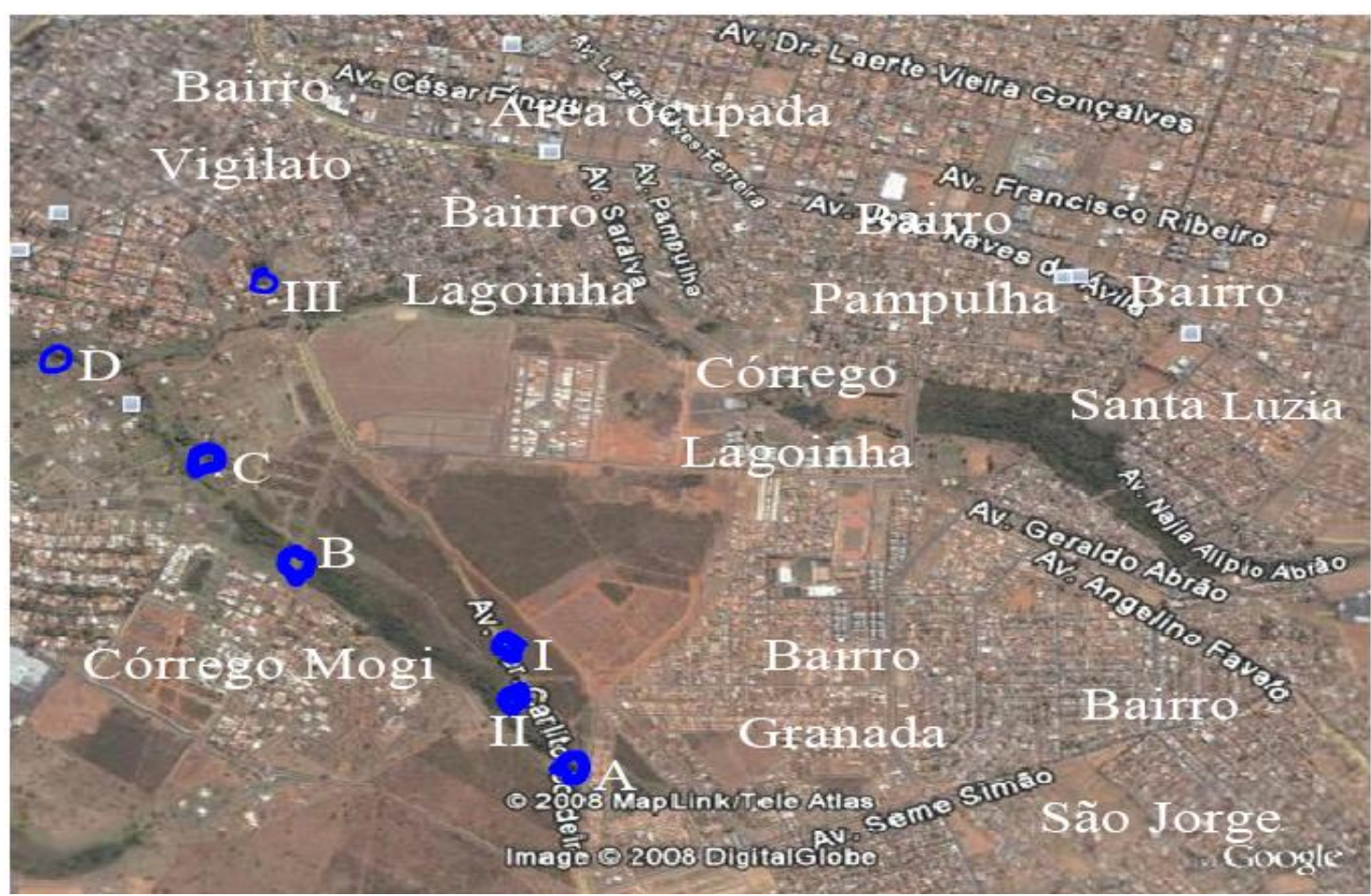

Figura 1 - Pontos de coleta - córrego Mogi (A, B e C) - córrego Lagoinha (ponto D) - Escoamento sarjeta (pontos I e III) e escoamento sob a vegetação APP (ponto II). Fonte: The living earth, 2008.

\section{3 - Discussão de dados}

Caracterização granulométrica do solo

A curva granulométrica foi obtida pelo método convencional de peneiramento e ou pipetagem das partes finas do solo. As peneiras utilizadas foram as de $n^{\circ} 4,10,16,30,40,60$, 100, 200, segundo as normas da (ABNT, 1984). As partículas que passaram na peneira 200 foram submetidas ao ensaio de sedimentação, segundo a NBR 7181/1984. Os resultados revelaram um predomínio de areia silto-argilosa de granulação fina (grãos menores que 1 $\mathrm{mm}$ ) no solo da superfície da bacia e nos sedimentos carreados pelas águas pluviais, conforme mostrado nas Figuras 2 e 3. 


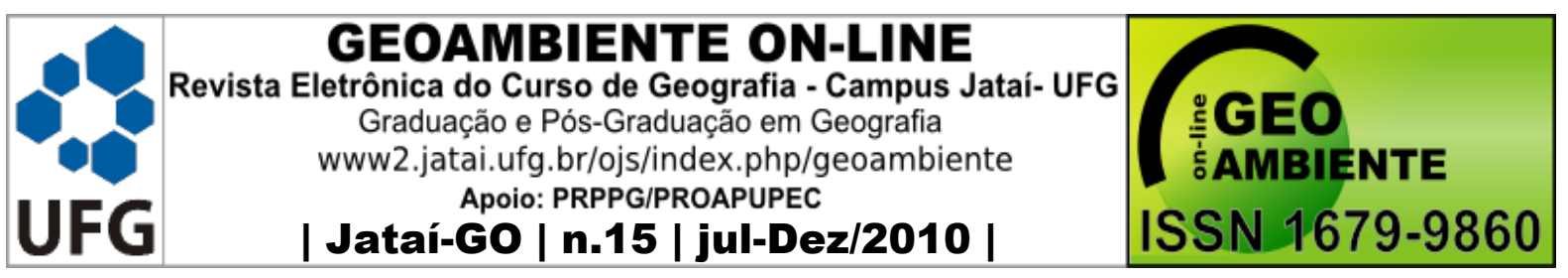

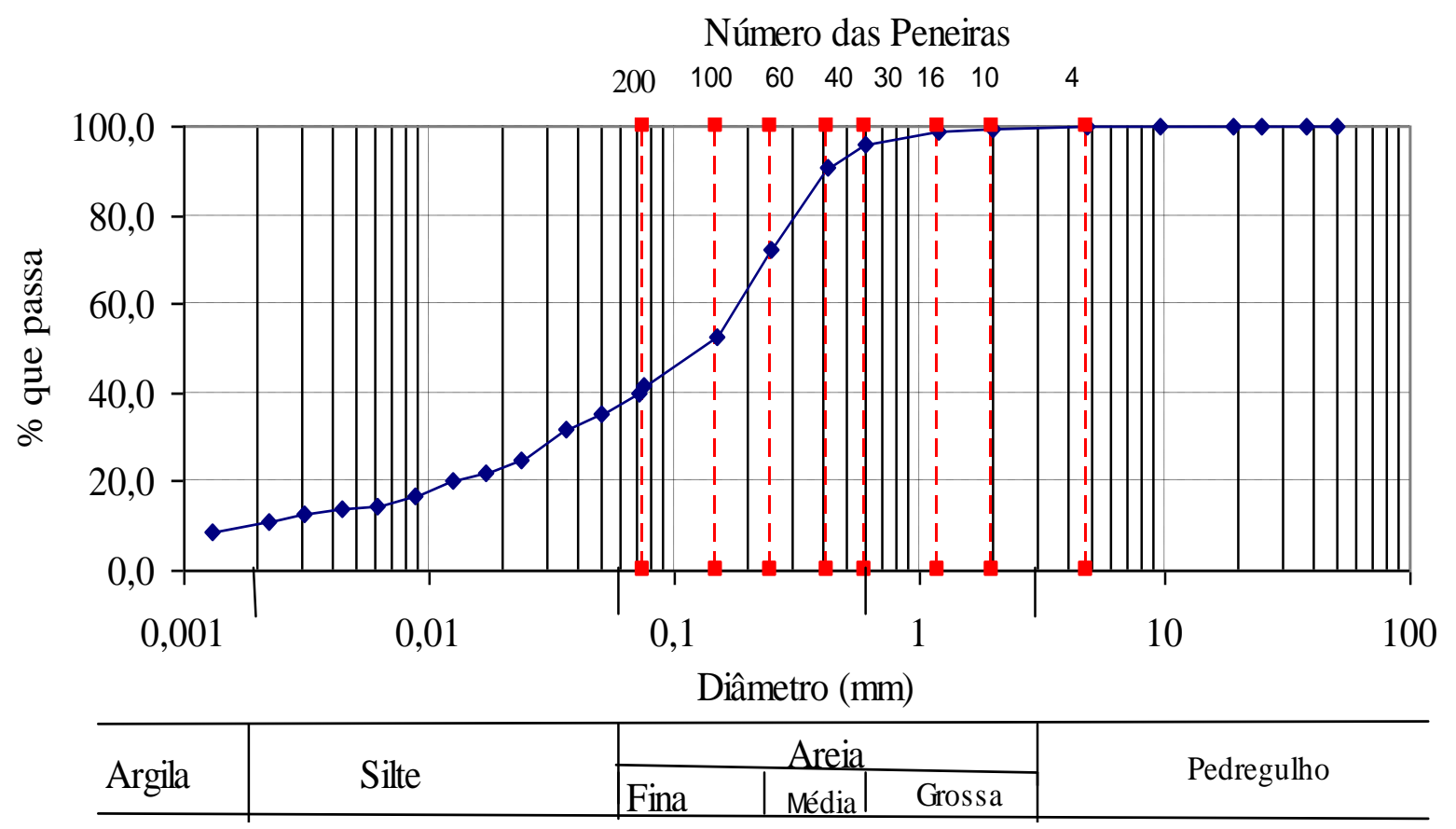

Figura 2 - Curva granulométrica do solo carreado pelas águas pluviais

Número das Peneiras

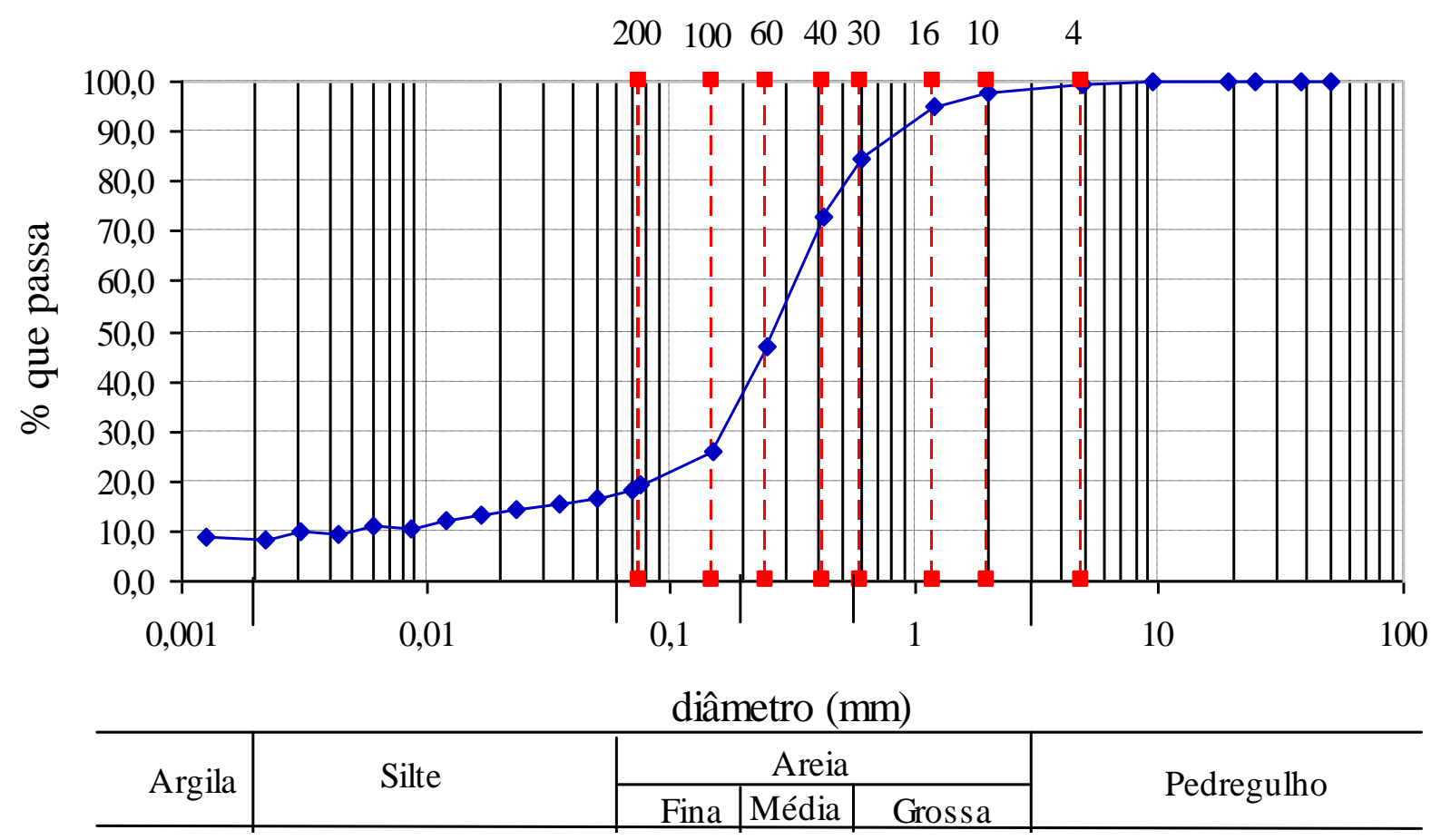

Figura 3 - Curva granulométrica do solo da Bacia 


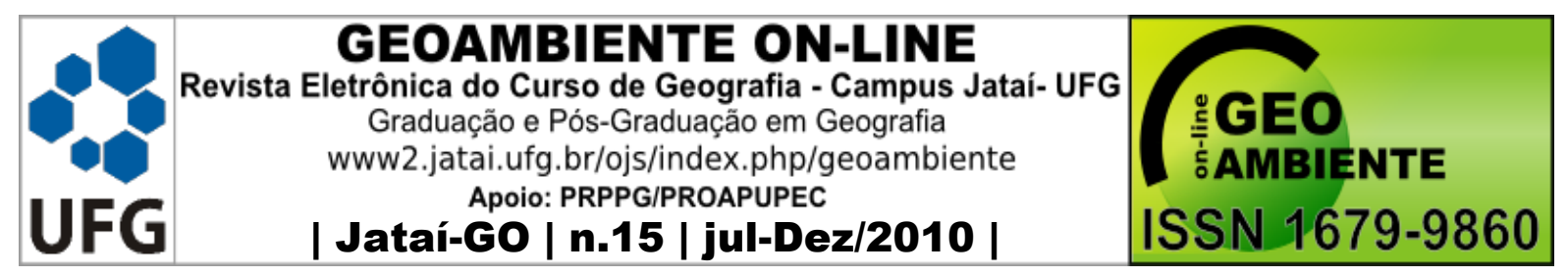

A Figura 2 mostra que $40 \%$ dos sedimentos carreado pelas águas pluviais passaram pela peneira $\mathrm{n}^{\circ} .200$ e $90 \%$ dos sedimentos finos passam pela peneira $\mathrm{n}^{\circ} 40$.

De acordo com os dados analisados (Figura 2) $40 \%$ dos sedimentos carreado pelas águas pluviais passaram pela peneira $\mathrm{n}^{\circ} .200$ e $90 \%$ dos sedimentos finos passam pela peneira $\mathrm{n}^{\circ} 40$

Na Figura 2 especifica-se que 20\% dos sedimentos do solo da microbacia passaram pela peneira 200, os quais foram analisados pelo método de sedimentação. Além disso, demonstra que $72 \%$ dos sedimentos passaram pela peneira 40 .

\section{Caracterização química do solo sedimentado}

Os valores das concentrações de cobre, zinco e ferro carreados pelo escoamento superficial são mostrados na Tabela 2. Os dois primeiro parâmetros são inferiores aos da pesquisa da CETESB, 2005.

Tabela 2 - Valores de referência de cobre e zinco no solo e teores naturais de ferro no solo.

\begin{tabular}{r|c|c|c}
\hline PARÂMETRO & Dados Atuais. & Dados da CETESB $^{(1)}$ & TEORES NATURAIS $^{(2)}$ \\
\hline Cobre $\mathrm{mg} / \mathrm{kg}$ & 12 & 35 & - \\
\hline Zinco mg/kg & 26 & 60 & - \\
\hline Ferro $\mathrm{mg} / \mathrm{kg}$ & 16.907 & - & 25.000 \\
\hline
\end{tabular}

O teor destes metais no material sedimentado pelo escoamento urbano, possivelmente, foi transportado pelo escoamento da sarjeta oriundo do solo a montante deste local, e depositado na APP. Estes metais, contidos no solo, influenciaram nos valores dos ensaios no escoamento sobre a APP e no escoamento fluvial do córrego Mogi e Lagoinha.

Qualidade do escoamento superficial da microbacia do Córrego Mogi 


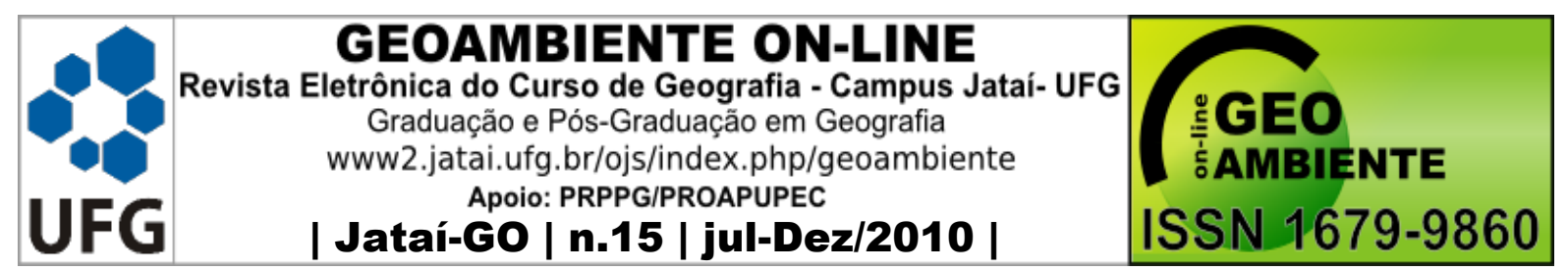

As coletas das amostras da água foram realizadas em campo, nos pontos descritos, anteriormente, nos dias 5 de fevereiro, 1 de maio, 3 de maio, 21 de julho, 5 de setembro e 21 de setembro de 2008 .

$\mathrm{Na}$ Tabela 3 estão resumidas as alturas de precipitação no dia de coleta de dados e as condições pluviométricas antecedentes à coleta.

Tabela 3 - Resumo das condições pluviométricas das coletas da área experimental.

\begin{tabular}{|c|c|c|c|}
\hline Coletas & Data & $\begin{array}{c}\text { Chuva } \\
\begin{array}{c}\text { Acumulada em } 24 \mathrm{~h} \\
(\mathrm{~mm})\end{array}\end{array}$ & Condições antecedentes \\
\hline 1 & $5 / 2 / 08$ & $\mathrm{~h}=35 \mathrm{~mm}$ & $\begin{array}{l}\text { Os primeiros } 24 \mathrm{~mm} \text { ocorreram } 2 \text { horas antes da Coleta e após } \\
\text { nove dias }(27 / 01 \text { a } 04 / 2 / 08) \text { chuvosos, totalizando } 205 \mathrm{~mm} \text {. }\end{array}$ \\
\hline 2 & $1 / 5 / 08$ & $\mathrm{~h}=38 \mathrm{~mm}$ & $\begin{array}{l}\text { Os primeiros } 25 \mathrm{~mm} \text { ocorreram } 22 \mathrm{~h} 30 \mathrm{~min} \text { antes da Coleta e após } \\
\text { oito dias sem chuva (23/4 a 30/4/08). }\end{array}$ \\
\hline 3 & $3 / 5 / 08$ & $\mathrm{~h}=7 \mathrm{~mm}$ & $\begin{array}{l}\text { Sendo que } 4,4 \mathrm{~mm} \text { ocorreram das } 6 \mathrm{~h} \text { às } 21 \text { horas do dia anterior, } \\
\text { isto é } 11 \text { horas antes da chuva que foi feita a coleta das amostras. }\end{array}$ \\
\hline 4 & 21/7/08 & Período seco & $\begin{array}{l}\text { Cinqüenta dias sem chuva, segundo dados da estação } \\
\text { Climatológica do Instituto de geografia (UFU, 2008). }\end{array}$ \\
\hline 5 & $5 / 9 / 08$ & Período seco & Noventa e quatro dias sem chuva (UFU, 2008). \\
\hline 6 & $21 / 9 / 08$ & $\mathrm{~h}=15 \mathrm{~mm}$ & $\begin{array}{l}\text { Os primeiros } 11 \mathrm{~mm} \text { ocorreram } 3 \text { horas antes da coleta e após } \\
110 \text { dias sem chuva. }\end{array}$ \\
\hline
\end{tabular}

A consideração dos dados pluviométricos foi importante para a interpretação dos resultados dos ensaios da água da área experimental. Para cada dia de coleta ocorrida no período chuvoso foi analizado o hietograma (Figura 4) do período anterior 

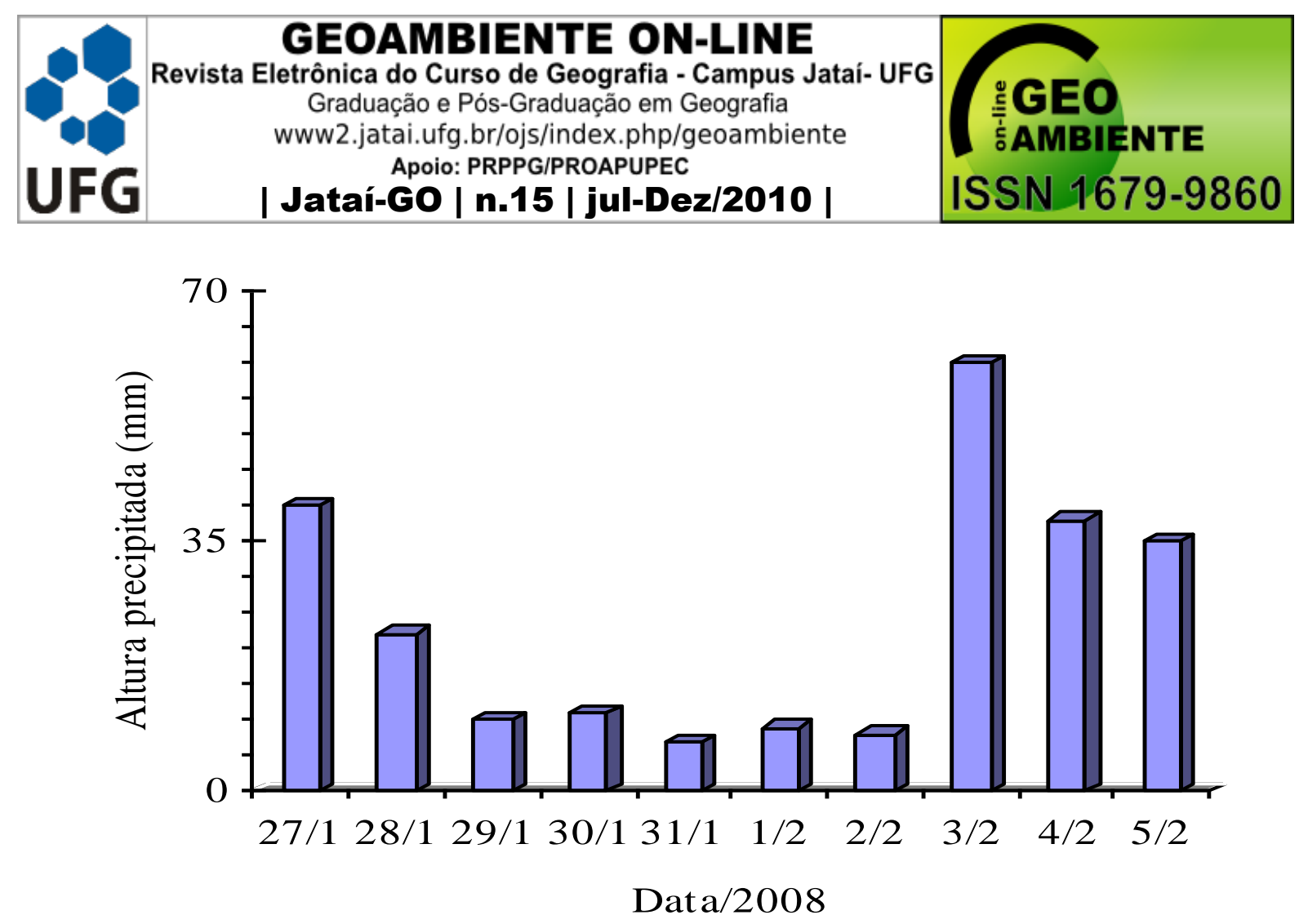

Figura 4 - Situação pluviométrica do período referente à coleta do dia 5/2/08 na bacia do córrego Mogi

Os dados mostrados na Tabela 4 referentes às coletas do córrego Mogi (ponto C) e do córrego Lagoinha (ponto D), após período longo sem chuva (21/7 e 5/9/08), mostram que os referidos córregos atendem aos limites da classe 3 da Resolução 357/05 do CONAMA. Os resultados de DBO, cobre e ferro no escoamento fluvial do córrego Lagoinha (ponto D) e cobre e ferro no escoamento fluvial do córrego Mogi (pontos C) estão ligeiramente superiores aos limites da classe 2 .

Tabela 4 - Resultados de ensaios realizados na área experimental do Córrego Mogi nos dias de coleta.

\begin{tabular}{|c|c|c|c|c|c|c|c|c|c|c|}
\hline \multirow{5}{*}{$\begin{array}{r}5 / 2 / 08 \\
h= \\
35 \mathrm{~mm}\end{array}$} & Local & $\overline{\mathrm{pH}}$ & $\begin{array}{r}\text { Turbidez } \\
\text { UNT } \\
\end{array}$ & $\begin{array}{l}\mathrm{DBO} \\
\mathrm{mg} / \mathrm{L}\end{array}$ & $\begin{array}{l}\text { Zinco } \\
\mathrm{mg} / \mathrm{L}\end{array}$ & $\begin{array}{c}\text { Cobre } \\
\mathrm{mg} / \mathrm{L}\end{array}$ & $\begin{array}{l}\text { Ferro } \\
\mathrm{mg} / \mathrm{L}\end{array}$ & $\begin{array}{r}\text { OD } \\
\mathrm{mg} / \mathrm{L}\end{array}$ & $\begin{array}{r}\mathrm{T} \\
{ }^{\circ} \mathrm{C} \\
\end{array}$ & $\begin{array}{r}\mathrm{SST} \\
\mathrm{mg} / \mathrm{L}\end{array}$ \\
\hline & Ponto A & 6,97 & 91,40 & 26,00 & N.D & 0,060 & 0,190 & 6,10 & 24 & 24,90 \\
\hline & Ponto B & 6,86 & 48,10 & 22,00 & N.D & 0,050 & 0,040 & 6,70 & 24 & 20,50 \\
\hline & Ponto I & 6,24 & 431,00 & 197,00 & N.D & N.D & N.D & 2,60 & 24 & 171,00 \\
\hline & Ponto II & 7,08 & 85,30 & 26,00 & N.D & 0,080 & 0,180 & 5,60 & 24 & 31,50 \\
\hline \multirow{3}{*}{$\begin{array}{r}2) \\
1 / 5 / 08\end{array}$} & Ponto A & 6,96 & 26,20 & 9,80 & N.D & 0,030 & 0,270 & 7,20 & 23 & 12,50 \\
\hline & Ponto B & 6.70 & 5,92 & 10,34 & N.D & 0,040 & 0,780 & 6.50 & 23 & 3,00 \\
\hline & Ponto I & 6,64 & 13,88 & 18,60 & N.D & 0,030 & 3,940 & 7,1 & 23 & 17,25 \\
\hline
\end{tabular}




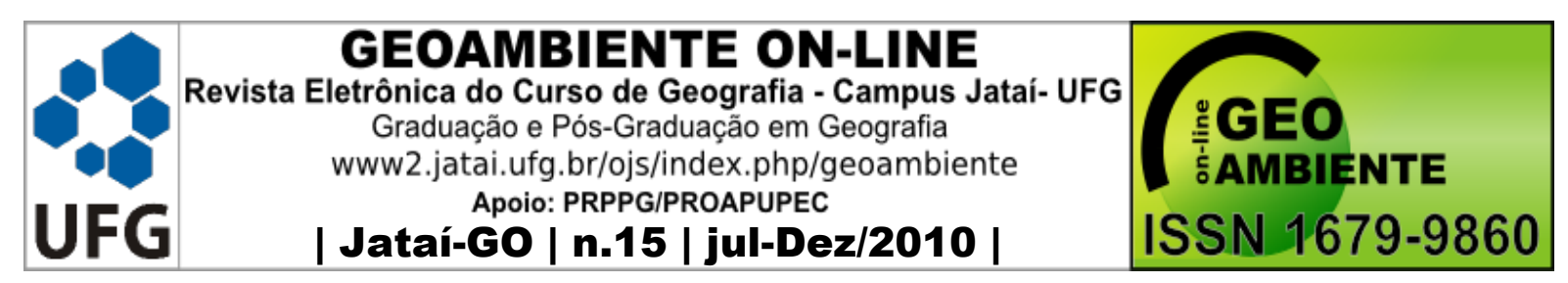

\begin{tabular}{|c|c|c|c|c|c|c|c|c|c|c|}
\hline $\mathrm{h}=$ & Ponto II & 7,36 & 16,14 & 16,70 & N.D & 0,090 & 0,160 & 5,20 & 23 & 9,50 \\
\hline \multirow{4}{*}{$\begin{array}{r}3 / 5 / 08 \\
\mathrm{~h}=\end{array}$} & Ponto A & 6,91 & 37,20 & 11,80 & N.D & 0,080 & N.D & 4,90 & 24 & 15,75 \\
\hline & Ponto B & 6,76 & 5,18 & 11,70 & N.D & 0,010 & 0,890 & 8,10 & 24 & 9,75 \\
\hline & Ponto I & 6,32 & 137,00 & 225,00 & N.D & N.D & N.D & 2,60 & 24 & 152,00 \\
\hline & Ponto II & 7,25 & 36,10 & 16,50 & N.D & 0,020 & 0,340 & 5,80 & 24 & 44,00 \\
\hline \multirow{2}{*}{$\begin{array}{r}4 \text { (4) } \\
\text { 50/7/2008 } \\
2 / 9 / 20\end{array}$} & Ponto C & 7,12 & 5,67 & 4,90 & 0,010 & 0,010 & 0,355 & 7,20 & 22 & 1,00 \\
\hline & Ponto D & 7,47 & 2,98 & 6,20 & 0,010 & 0,010 & 0,453 & 7,50 & 24 & 2,60 \\
\hline \multirow{6}{*}{$\begin{array}{r}6 \text { ) } \\
21 / 9 / 08 \\
\mathrm{~h}= \\
15 \mathrm{~mm}\end{array}$} & Ponto A & 6,80 & 30,90 & 21,00 & 0,010 & 0,010 & 1,600 & 3,10 & 22 & 32,00 \\
\hline & Ponto B & 6,61 & 69,60 & 14,80 & 0,020 & 0,010 & 0,0183 & 6,00 & 22 & 58,00 \\
\hline & Ponto C & 6,90 & 114,00 & 21,00 & 0,010 & 0,010 & 1,200 & 5,40 & 22 & 75,50 \\
\hline & Ponto D & 7,21 & 146,00 & 35,40 & 0,050 & 0,010 & 1,600 & 4,10 & 22 & 136,00 \\
\hline & Ponto I & 7,53 & 71,70 & 36,10 & 0,018 & 0,010 & 0,562 & 3,70 & 22 & 76,50 \\
\hline & III & 7,95 & 527,00 & 124,0 & 0,05 & 0,010 & 1,200 & 3,20 & 22 & 755,00 \\
\hline
\end{tabular}

N.D = Não Detectado e $\mathrm{h}=$ altura precipitada. Obs: Pontos I e III (escoamento de sarjeta); II vegetação e os pontos A, B, C (escoamento fluvial do córrego Mogi) e D (escoamento fluvial do córrego Lagoinha).

Ao comparar o escoamento da sarjeta na área em processo de ocupação (ponto I) com a sarjeta de uma área ocupada (ponto III) no ensaio $\mathrm{n}^{\circ}$ 6, obteve-se um valor maior de poluentes no segundo ponto e um menor valor de OD, mostrando o impacto da ocupação urbana.

Quanto ao pH, mostrado na Figura 5, não houve grandes variações. Na vegetação (ponto II), o pH mostrou-se mais básico que no escoamento fluvial do córrego Mogi e do córrego Lagoinha. Em todos os pontos, apresentou resultados dentro dos limites da classe 2 da Resolução 357/05 do CONAMA. 

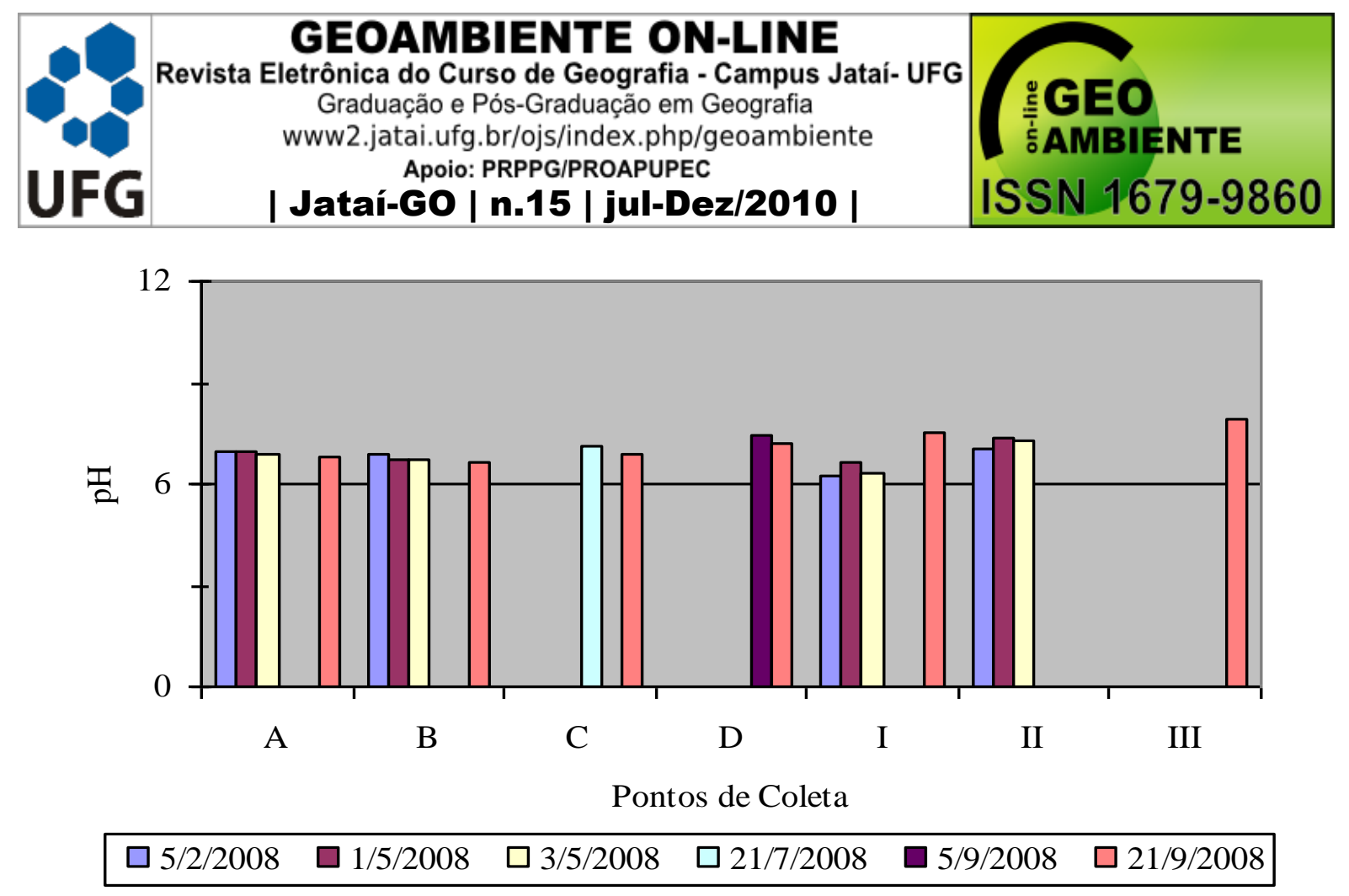

Figura 5 - Resultado de pH no escoamento da microbacia do córrego Mogi e córrego Lagoinha.

No escoamento fluvial no córrego Mogi (ponto B), em todas as coletas analisadas, ocorreu uma redução na turbidez em relação ao afloramento do lençol freático (ponto $\mathrm{A}$ ), devido à influência da área brejosa, exceto na coleta do dia 21/9/08. No ponto a jusante de B no escoamento fluvial do córrego Mogi (ponto C), devido aos serviços de corte e aterro no entorno desta área com ocupação urbana, apresentou um leve aumento em relação ao resultado do afloramento do lençol freático (ponto A) na coleta do dia 21/9/08.

Os valores de turbidez no córrego Mogi (pontos C) e córrego Lagoinha (ponto D), no período seco, com coleta nos dias 21/7 e 5/9, revelam uma tendência de não existência de processo erosivo significativo no leito natural, quando não ocorre enchente. Porém, devido ao fato que, mesmo sem turbidez no escoamento pode ocorrer araste das partículas de fundo, para conclusão definitiva é necessária a implementação de campanha de medição de descarga sólida (suspensão e arrasto) e de batimetria periódicas.

Nos dias chuvosos (5/2/08 e 21/9/08) o escoamento na sarjeta (pontos I e III) ultrapassou o limite de turbidez (100 UNT ou FTU) das classes 2 e 3 da Resolução do CONAMA. No escoamento fluvial este limite só foi ultrapassado nos pontos de jusante do 


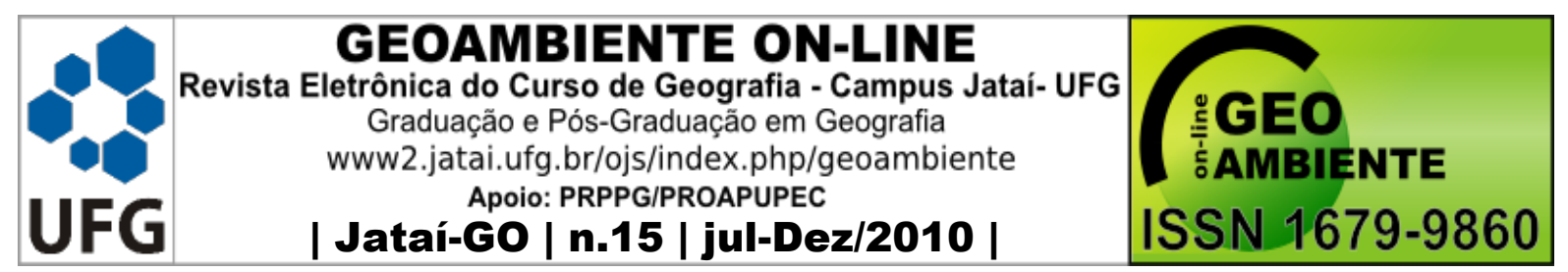

córrego Mogi e do córrego Lagoinha (Pontos C e D), ver Figura 6, pois recebiam enxurradas da área ocupada ou em plena fase de ocupação.

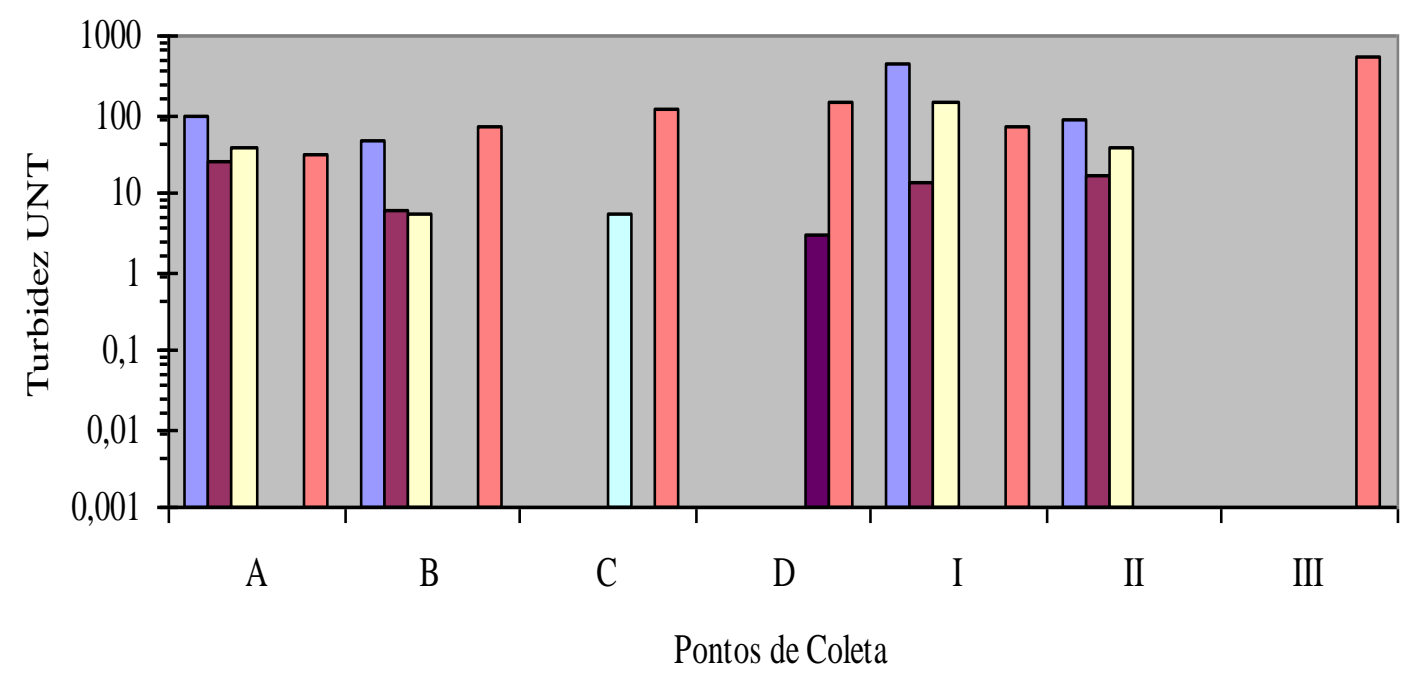

$\begin{array}{llllll}\square 5 / 2 / 2008 & \square 1 / 5 / 2008 & \square 3 / 5 / 2008 & \square 21 / 7 / 2008 & \square 5 / 9 / 2008 & \square 21 / 9 / 2008\end{array}$

Figura 6 - Resultado da turbidez no escoamento fluvial do córrego Mogi e Lagoinha.

O valor da turbidez na sarjeta da Rua Benjamim Alves dos Santos do bairro Lagoinha (ponto III) foi reduzido pela diluição no escoamento fluvial do córrego Lagoinha (ponto D).

O resultado do escoamento na APP (entre os pontos I e II) sofre uma leve redução da DBO, demonstrando sua importância na preservação da qualidade da água do córrego. A vegetação (ponto II) foi mais eficiente que a diluição no escoamento fluvial do córrego Mogi.

Os valores de DBO ultrapassaram os limites da classe 3 no escoamento fluvial, em ambos os córregos, no período chuvoso, já no período seco estão abaixo do limite desta classe em ambos os córregos como pode ser visto na Figura 7. 


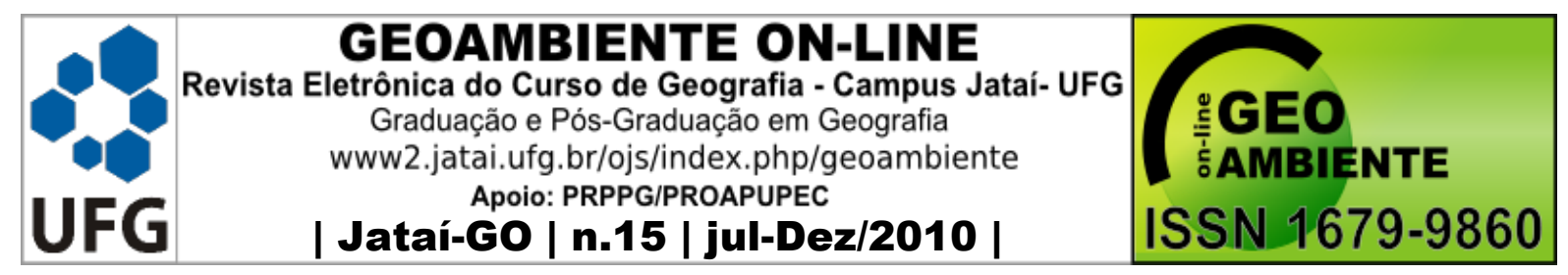

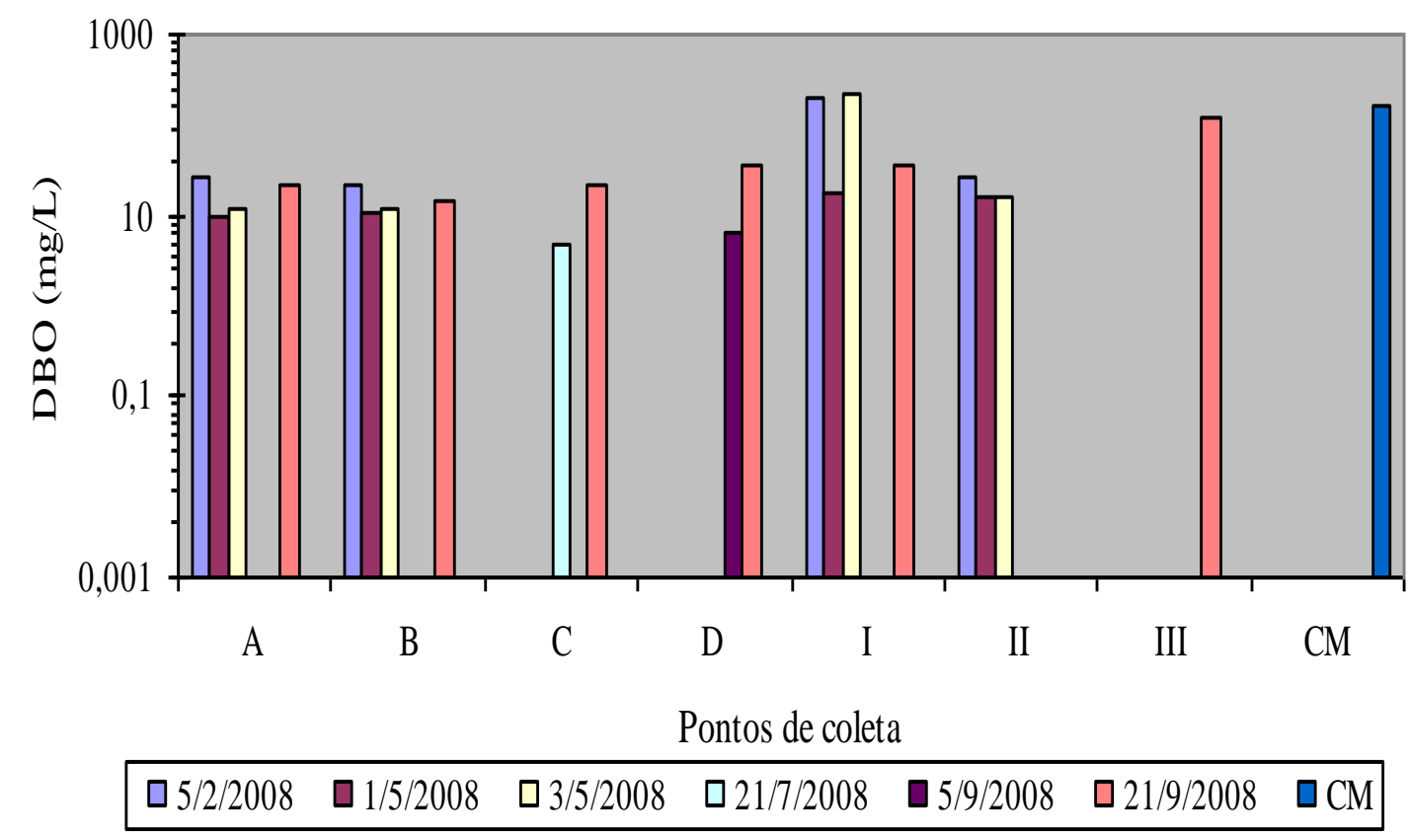

Figura 7 - Resultado da DBO no escoamento nos dias de coleta e o resultado do Córrego Mandaqui (CM) em SP.

O valor de DBO do escoamento da sarjeta tanto na área ocupada (ponto III) como na área em processo de ocupação (ponto I) está acima dos limites da classe 3.

O resultado de DBO do córrego Mandaqui, em São Paulo, foi superior a todos os dados no escoamento fluvial do córrego Mogi e do córrego Lagoinha, provavelmente em função processo de urbanização daquele, acumulando uma quantidade maior de resíduos orgânicos via escoamento superficial urbano.

A quantidade de zinco existente no sedimento carreado pelo escoamento de sarjeta foi de $26 \mathrm{mg} / \mathrm{Kg}$. Este valor influenciou no teor encontrado no córrego Mogi (pontos A, B e C) e no córrego Lagoinha (ponto D), mas mesmo assim, resultou em uma concentração inferior ao limite da classe 2 da Resolução do CONAMA, que é de $0,18 \mathrm{mg} / \mathrm{L}$.

O teor de zinco no escoamento fluvial (ponto B) mostrou-se superior ao afloramento do lençol freático (ponto A), ver Figura 8, devido à presença de zinco no solo desnudo da 


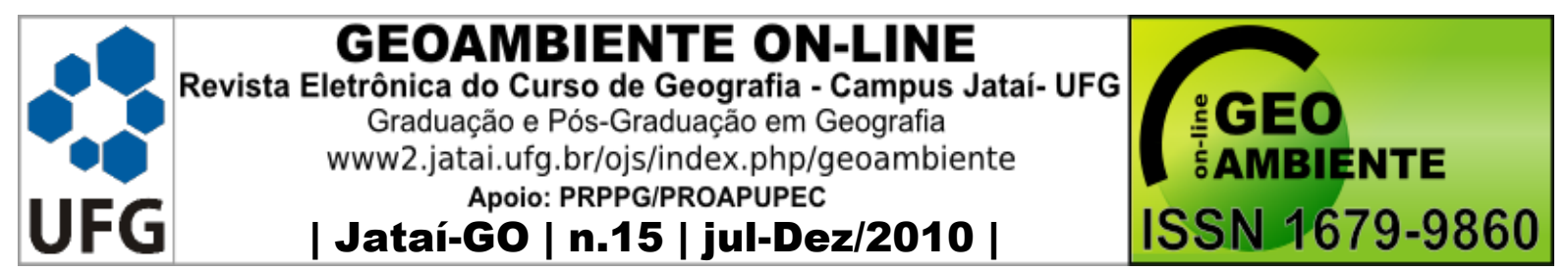

APP ou no sedimento carreado, porém ocorreu uma redução ao longo do escoamento no córrego Mogi.

O zinco não foi detectado nos ensaios dos dias 5/2/08, 1/5/08 e 3/5/08, possivelmente devido à baixa concentração de residências com equipamentos galvanizados e pouca circulação de automóveis; porém, foram detectadas uma concentração mínima nos ensaios dos dias 21/7, $5 / 9$ e 21/9/2008.

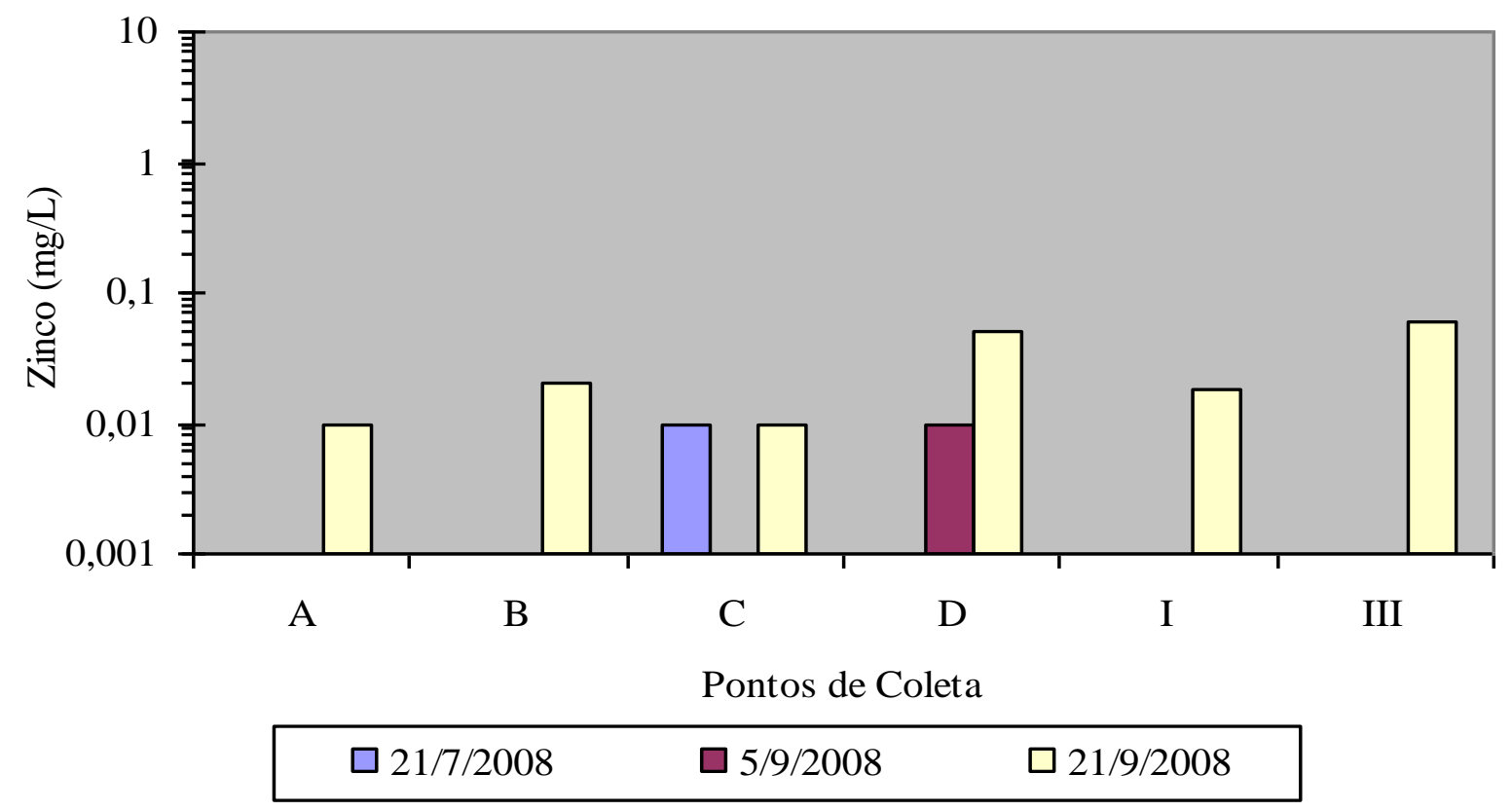

Figura 8 - Resultado de zinco na microbacia do córrego Mogi e Lagoinha.

O resultado obtido da concentração de cobre mostrado na Figura 9 é maior na área preservada (ponto II) e na área de afloramento do lençol freático (ponto A), o que pressupõe acúmulo deste metal no solo oriundo do escoamento da sarjeta (ponto I). Tendo em vista que o material depositado no solo da APP apresentou o valor de $12 \mathrm{mg} / \mathrm{Kg}$ deste elemento químico.

$\mathrm{Na}$ amostragem dos dias 5/2, 1/5 e 3/5 no escoamento fluvial do córrego Mogi (pontos A e B) a concentração de cobre está acima dos limites da Classe 2 da Resolução 357/05 do CONAMA (BRASIL, 2005), que é de 0,009 mg/L. 


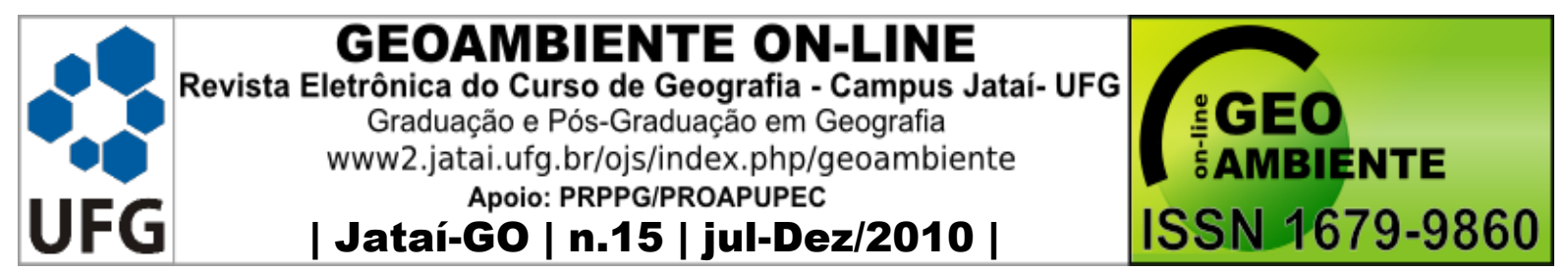

Os teores de cobre obtidos nas coletas dos dias 21/7/08 e 5/9/08 (período seco) e a coleta do dia 21/9/08, em ambos os córregos, estão abaixo dos limites da classe 3 da Resolução 357 do CONAMA, mostrados na Figura 9.

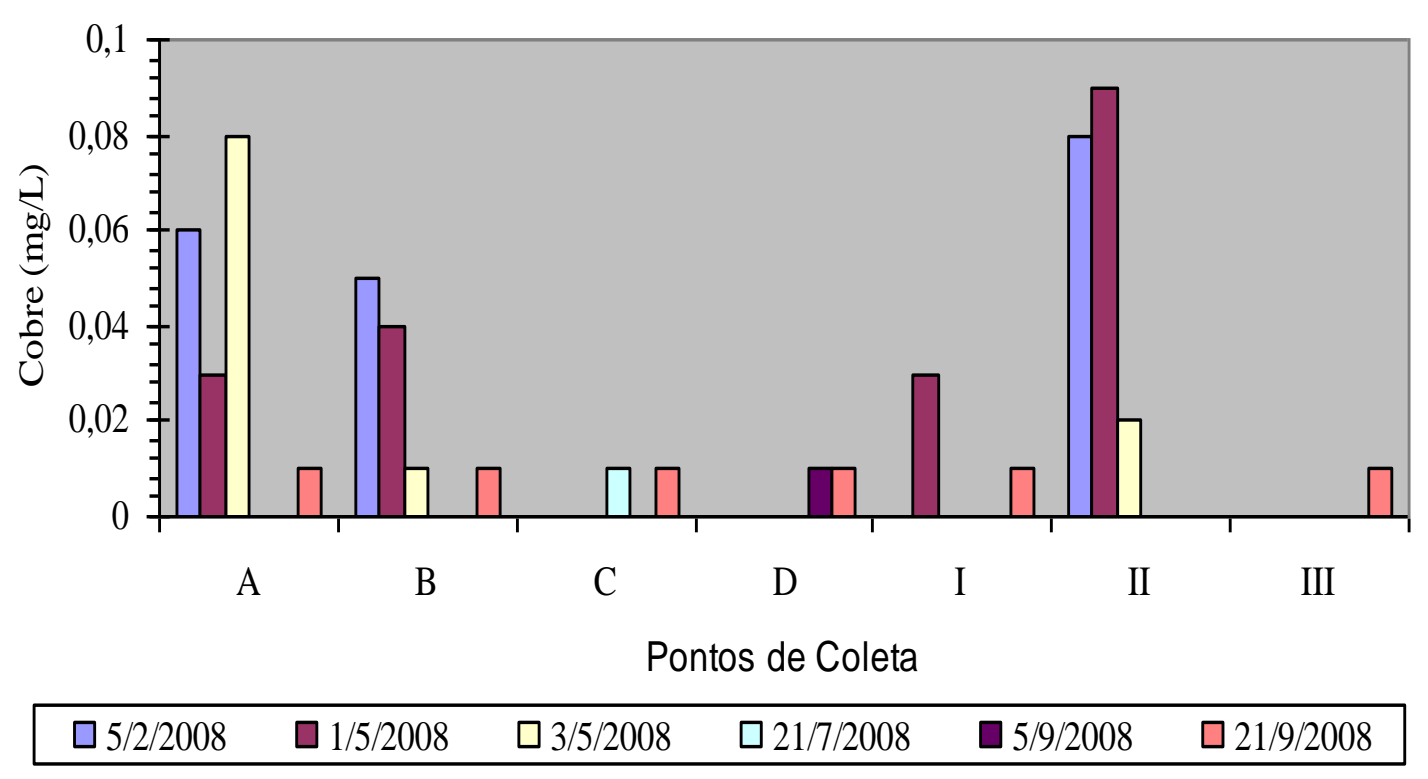

Figura 9 - Resultado de Cobre no escoamento nos dias de coleta.

Na Figura 10 é possível verificar que o teor de Ferro no escoamento da sarjeta (ponto I), do dia 1/5/08, foi reduzido na vegetação até o ponto II; já nos dados dos demais dias (5/2/08 e 3/5/08) não foram detectados, possivelmente devido às concentrações muito baixa ou falha na coleta. 

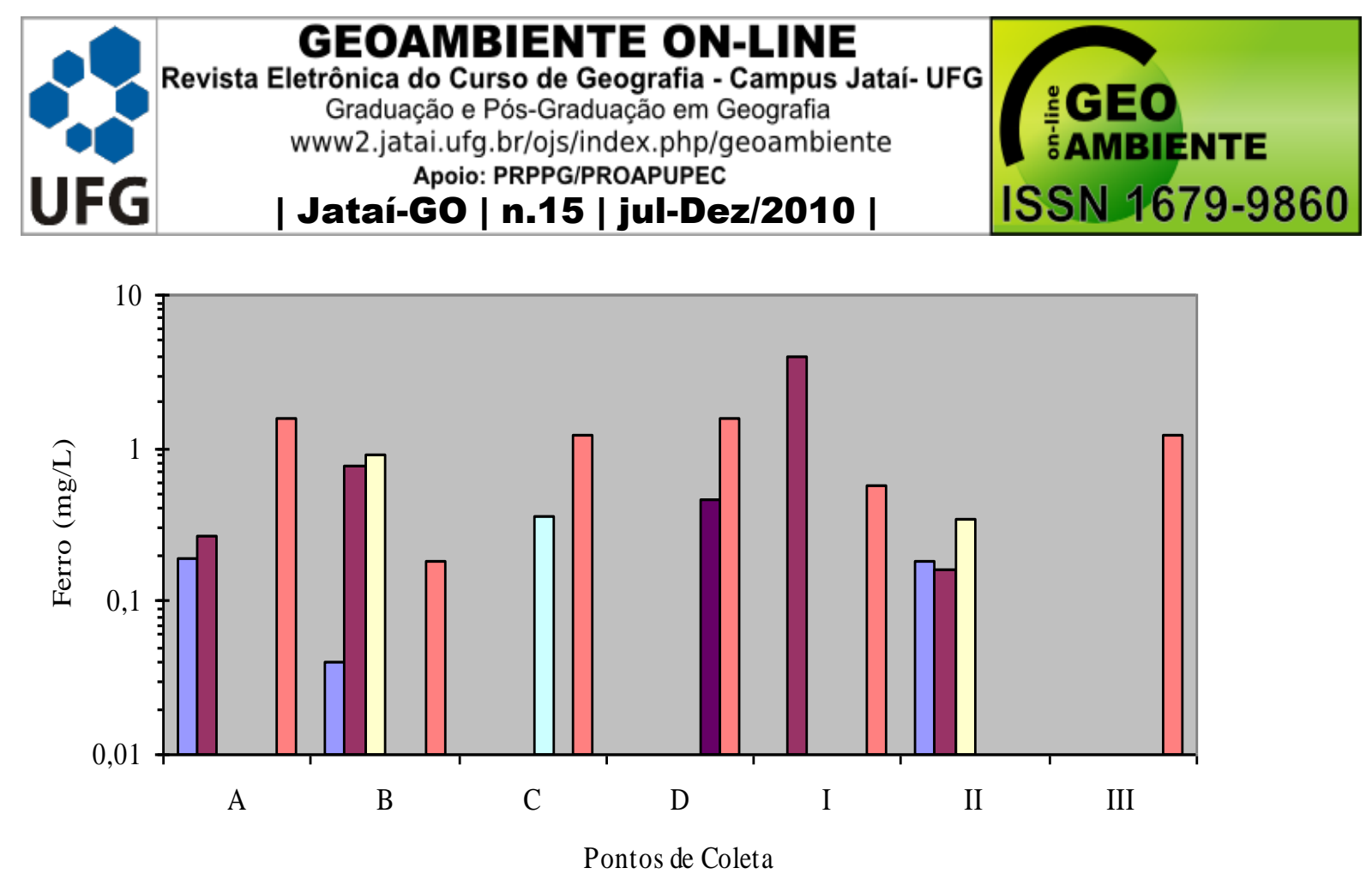

\begin{tabular}{|llllll|}
\hline$\square 05 / 02 / 2008$ & $\square 01 / 05 / 2008$ & $\square 03 / 05 / 2008$ & $\square 21 / 7 / 2008$ & $\square 5 / 9 / 2008$ & $\square 21 / 9 / 2008$ \\
\hline
\end{tabular}

Figura 10 - Resultado de Ferro no escoamento na bacia do córrego Mogi e Lagoinha.

O resultado da coleta do material depositado na APP, próximo ao ponto II, obteve resultado de 16.907 (mg/kg) de ferro, possivelmente oriundo do latossolo vermelho-escuro de origem basáltica. Isto provavelmente influenciou os resultados tanto na APP (ponto II) como no escoamento fluvial, porém todas as amostras apresentaram concentração de ferro abaixo dos limites da classe 3 da Resolução do CONAMA.

Os maiores valores de oxigênio (Figura 11) referem-se ao escoamento fluvial do córrego Mogi (ponto B), no dia 3/5/08. Em todas as amostras o escoamento fluvial apresenta dados superiores aos limites da classe 3 da Resolução 357/05 do CONAMA.

Na coleta do dia 1/5/08 o resultado de oxigênio dissolvido deve ter ocorrido devido a dissolução por algo, ou seja, entre os pontos I e II nos demais dias de coleta (5/2 e 3/5/08) houve incorporação de oxigênio.

O escoamento fluvial do córrego Lagoinha (ponto D) melhorou o Oxigênio Dissolvido (OD) da água no escoamento da sarjeta da área ocupada (ponto III) por que o trecho é turbulento, com a presença de corredeiras. 


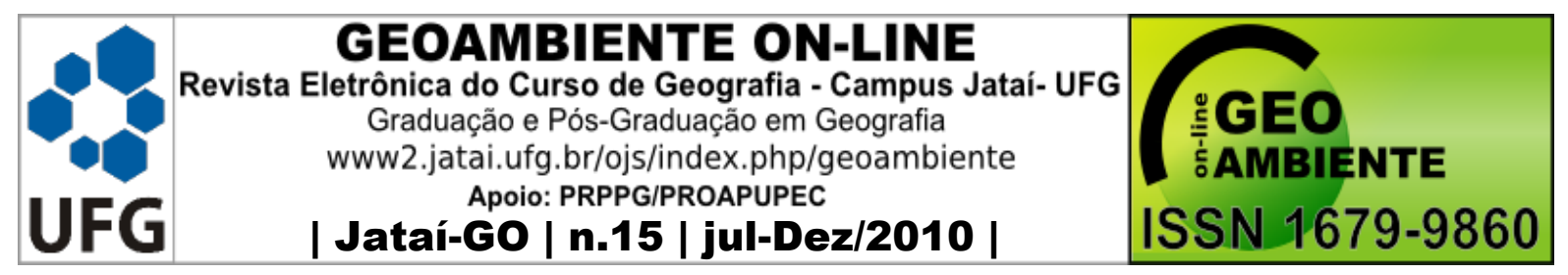

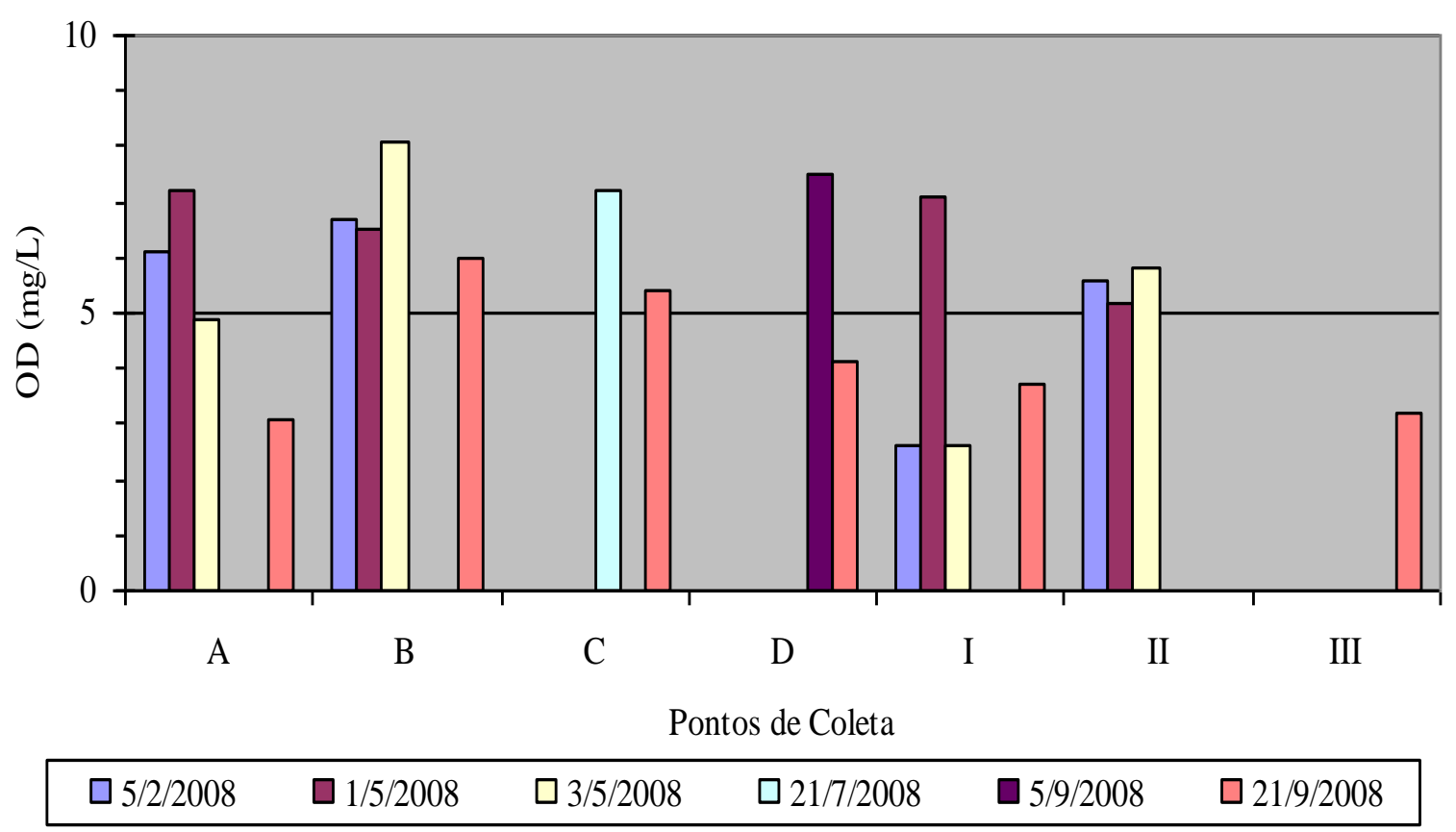

Figura 11 - Resultado de OD no escoamento nos dias de coleta.

As temperaturas apresentadas na Figura 12 mostraram-se estáveis em todos os pontos. Os resultados dos ensaios de temperatura do escoamento fluvial no córrego Mogi (pontos A, B e C) e no córrego Lagoinha (ponto D) estão inferiores ao limite fixado de $40^{\circ} \mathrm{C}$ na Classe 2 da Resolução 357/05 do CONAMA (BRASIL, 2005). Todas as temperaturas foram coletadas em horários e dias diferentes. 

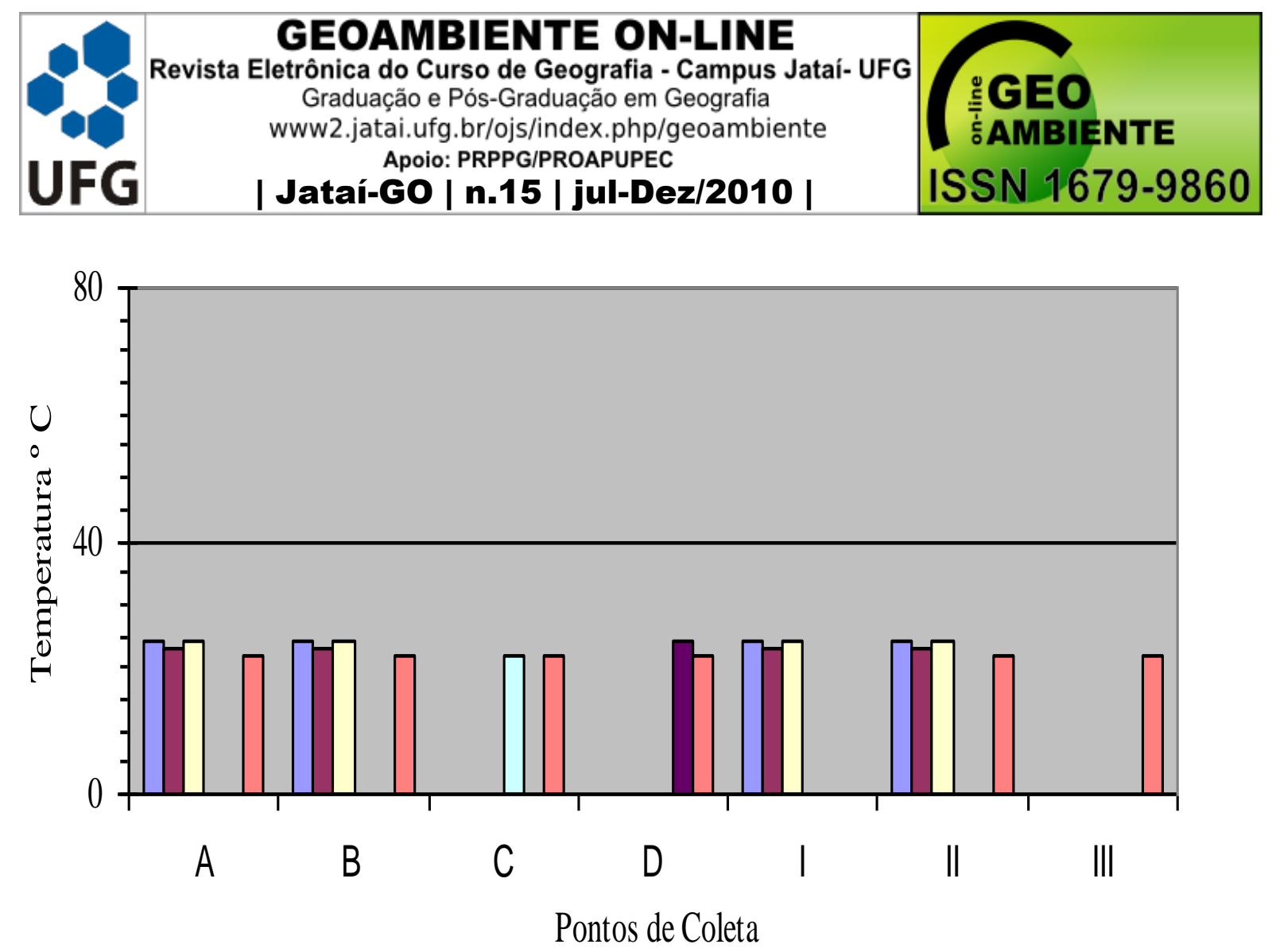

\begin{tabular}{lllllll}
\hline $05 / 02 / 2008$ & $\square 01 / 05 / 2008$ & $\square 03 / 05 / 2008$ & $\square 21 / 7 / 2008$ & $\square 5 / 9 / 2008$ & $\square 21 / 9 / 2008$
\end{tabular}

Figura12 - Resultado da temperatura do escoamento nos dias de coleta.

O teor de Sólidos Suspensos Totais (SST) no escoamento fluvial do córrego Mandaqui, em São Paulo, apresentou valores superiores aos dados do escoamento fluvial dos dias de coletas, devido à intensa edificação e circulação de veículos.

Os valores de SST (Figura13), dos córregos Mogi (pontos A, B e C) e Lagoinha (ponto D) foram bastante inferiores a $500 \mathrm{mg} / \mathrm{L}$, valor fixado para as Classes 2 da Resolução 357/05 do CONAMA (BRASIL, 2005).

O parâmetro de SST foi reduzido na vegetação (ponto II), Figura 13, em relação ao escoamento da sarjeta (ponto I), em todas as coletas realizadas. Essa redução se deu em função do atrito na grama, no capim, nos arbustos e outras barreiras de contenção e acumulação de resíduos do escoamento urbano ao passar por áreas de APP. 


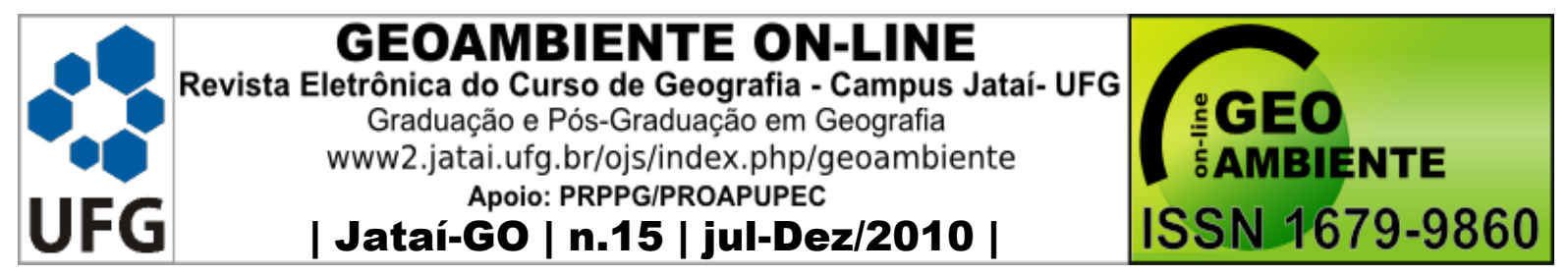

O escoamento fluvial no córrego Mogi (ponto B) apresentou uma redução do SST em relação ao afloramento do lençol freático (ponto A), por meio da diluição, em todas as coletas realizadas, com exceção do dia 21/9/08.

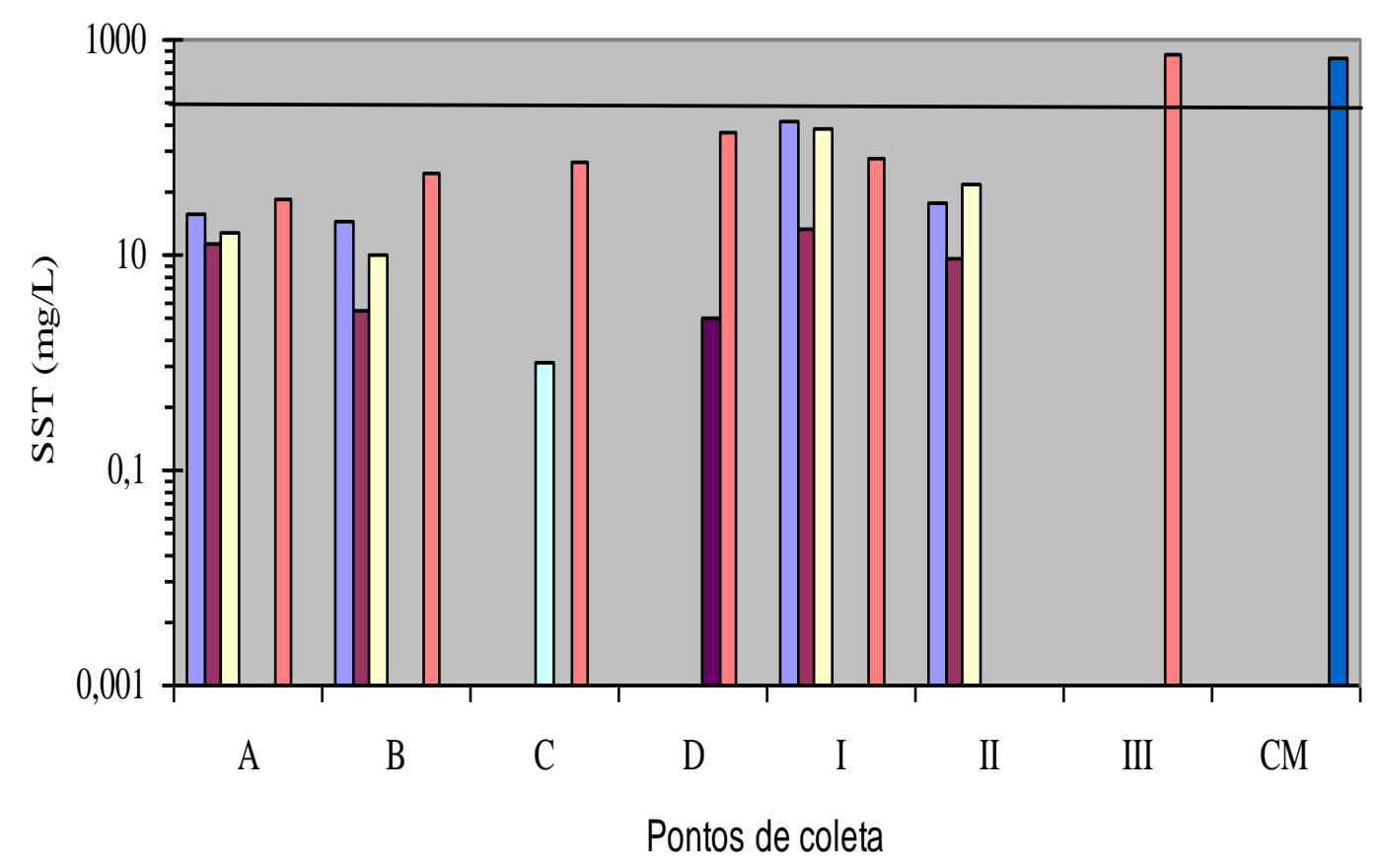

\begin{tabular}{|llllllll}
\hline$\square 05 / 02 / 2008$ & $\square 01 / 05 / 2008$ & $\square 03 / 05 / 2008$ & $\square 21 / 7 / 2008$ & $\square 5 / 9 / 2008$ & $\square 21 / 9 / 2008$ & $\square \mathrm{CM}$
\end{tabular}

Figura 13 - Resultado de SST no escoamento nos dias de coleta e no córrego Mandaqui (CM) em SP. Obs. CM significa Córrego Mandaqui

Na Tabela 5 são apresentados um resumo sucinto da análise dos dados obtidos na microbacia do córrego Mogi e a comparação com os valores encontrados na literatura.

Tabela 5 - Resumo dos resultados dos ensaios realizados na área de estudo.

\begin{tabular}{c|cc}
\hline DATA DAS COLETAS E & RESULTADOS \\
CONDIÇÕES ANTECEDENTES & \\
\hline
\end{tabular}




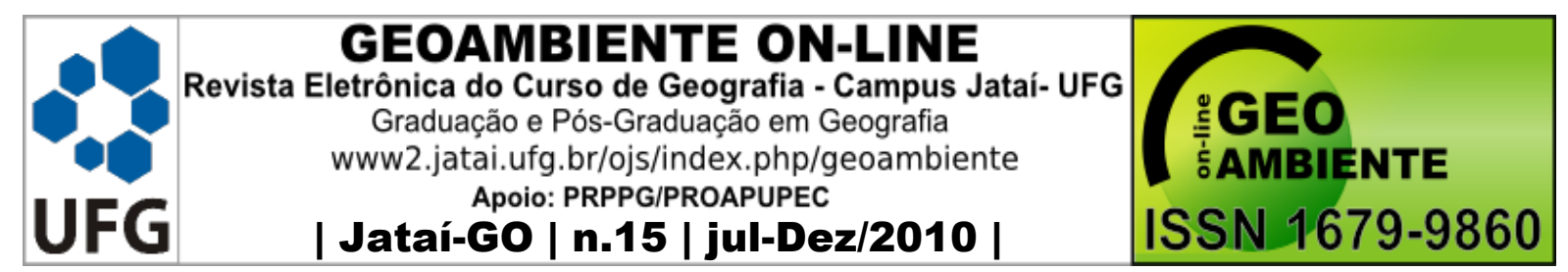

\begin{tabular}{|c|c|}
\hline $\begin{array}{l}\text { 5/2/08 }(35 \mathrm{~mm}) \text {, com } 9 \text { dias com } \\
\text { chuva antes da coleta precipitação } \\
\text { total de } 205 \mathrm{~mm})\end{array}$ & $\begin{array}{l}\text { O resultado do escoamento fluvial no córrego Mogi (pontos A e B) foi } \\
\text { capaz de melhorar a qualidade da água do enchorro a ponto de mantê-lo } \\
\text { na classe 2, exceto os parâmetros: DBO e cobre. O teor de poluentes no } \\
\text { escoamento da sarjeta (ponto I) ao passar pela vegetação ou pelo setor }\end{array}$ \\
\hline $\begin{array}{l}\text { 1/5/08 ( } 38 \mathrm{~mm}) \text {, com } 8 \text { dias sem } \\
\text { chuva antes da coleta }\end{array}$ & $\begin{array}{l}\text { O resultado do escoamento fluvial no córrego Mogi (ponto A e ponto } \\
\text { B) foi capaz de melhorar a qualidade da água do enchorro a ponto de } \\
\text { mantê-lo na classe } 3 \text {, com exceção para o parâmetro cobre e DBO. O } \\
\text { teor de poluentes no escoamento da sarjeta (ponto I) ao passar pela } \\
\text { vegetação ou setor preservado sofre redução significativa no resultado } \\
\text { de sedimentos e no melhoramento dos demais parâmetros, exceto } \\
\text { turbidez, cobre e OD. }\end{array}$ \\
\hline $\begin{array}{l}\text { 3/5/08 }(7 \mathrm{~mm}), 1 \text { dia sem chuva } \\
\text { antes da coleta }\end{array}$ & $\begin{array}{l}\text { O resultado do escoamento fluvial no córrego Mogi (pontos A e B) foi } \\
\text { capaz de melhorar a qualidade da água do enchorro a ponto de mantê-lo } \\
\text { na classe 3, com exceção da DBO. O teor de poluentes no escoamento } \\
\text { da sarjeta (ponto I) ao passar pela vegetação sofre redução significativa } \\
\text { no resultado de sedimentos e no melhoramento dos demais parâmetros. }\end{array}$ \\
\hline $\begin{array}{l}\text { 21/7/08, com } 50 \text { dias sem chuva } \\
\text { (período seco) }\end{array}$ & $\begin{array}{l}\text { O valor das amostras coletadas no córrego Mogi (ponto C) apresentou } \\
\text { dados próximos aos limites da classe } 3 \text { da Resolução do CONAMA. } \\
\text { Sendo que em relação à classe } 2 \text { apenas as concentrações de cobre e } \\
\text { ferro são ligeiramente maiores que os limites, devido à existência no } \\
\text { solo da microbacia. }\end{array}$ \\
\hline $\begin{array}{l}\text { 5/9/2008, com } 94 \text { dias sem chuva } \\
\text { (período seco) }\end{array}$ & $\begin{array}{l}\text { O resultado do escoamento fluvial no córrego Lagoinha (ponto D) } \\
\text { apresentou valores próximos aos limites da classe } 3 \text { da Resolução do } \\
\text { CONAMA. Sendo que em relação à classe } 2 \text { apenas as concentrações } \\
\text { de DBO, de cobre e de ferro são ligeiramente maiores que os limites, } \\
\text { devido à existência destes no sedimento carreado pelo deflúvio urbano } \\
\text { (ponto I). }\end{array}$ \\
\hline $\begin{array}{l}\text { 21/9/2008 }(15 \mathrm{~mm}) \text {, com } 110 \text { dias } \\
\text { sem chuva. }\end{array}$ & $\begin{array}{l}\text { No resultado do escoamento fluvial no córrego Mogi (pontos A, B e C) } \\
\text { houve um acréscimo de montante para jusante dos valores de turbidez, } \\
\text { SST e DBO, sendo que no último ponto de coleta (ponto C) os } \\
\text { parâmetros de DBO e turbidez são maiores que os limites da classe } 3 \text {. O } \\
\text { valor da água coletada no escoamento da sarjeta (ponto III) obteve } \\
\text { redução no escoamento fluvial do córrego Lagoinha, exceto o } \\
\text { parâmetro ferro. O teor de poluentes no escoamento da sarjeta da área }\end{array}$ \\
\hline
\end{tabular}




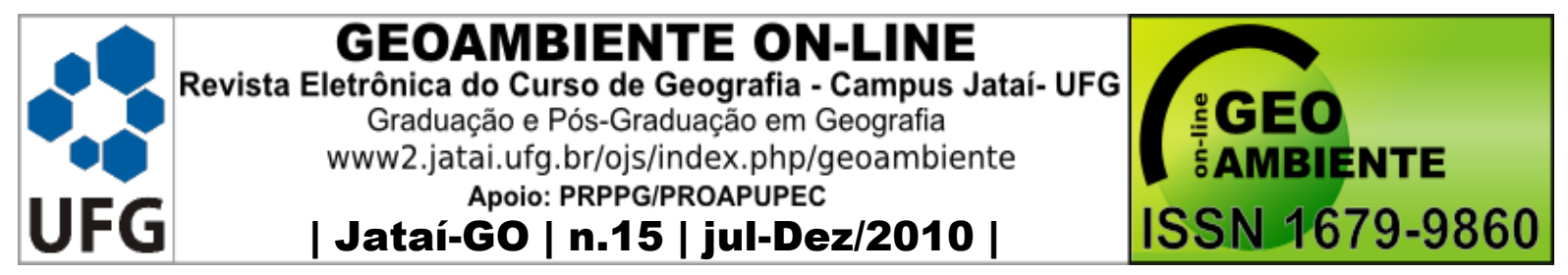

ocupada (ponto III) apresentou valores superiores à área não ocupada (ponto I), mostrando o efeito da ocupação urbana.

\section{4 - Considerações Finais}

A quantidade de poluentes carreados pelo escoamento urbano está relacionada à quantidade de chuva, às condições de limpeza dos pavimentos, ao processo de urbanização e à intensidade da circulação de veículos, dentre outros. Os estudos acerca da temática ambiental afirmam que áreas verdes, em fundos de vales nas cidades, são importantes para a melhoria da qualidade do escoamento superficial urbano. Os espaços de cobertura vegetal são locais importantes para a retenção dos poluentes do escoamento superficial urbano, pois provocam a sedimentação dos mesmos antes que eles cheguem aos cursos de água.

Para a coleta de água foi levada em consideração a não ocupação da área urbanizada, pois a ocupação da mesma polui os córregos urbanos com resíduos carreados pela poluição difusa e por pontos específicos de poluições quando se canaliza o escoamento superficial.

Com relação à qualidade da água do escoamento superficial foram detectadas baixas concentrações de poluentes devido à urbanização sem ocupação; porém foram detectadas maiores quantidades destes na microbacia do córrego Lagoinha influenciada pela intensa ocupação urbana. Contribui para a redução dos poluentes, a existência da área de preservação natural. A qualidade da água do córrego Mogi do período chuvoso está de acordo com os limites da classe 3 da Resolução 357 do CONAMA (BRASIL, 2005) de acordo com os parâmetros avaliados, exceto o parâmetro de DBO e de cobre. A condição ambiental do córrego Mogi está próxima aos limites da classe 2, no período chuvoso, devido a um valor levemente superior de alguns parâmetros, como cobre, ferro e de DBO.

Os valores do escoamento da sarjeta nos pontos I e III foram de extrema relevância, na medida em que se compara uma área ocupada (córrego Lagoinha) com uma área em processo de ocupação (córrego Mogi). Neste sentido, os resultados dos ensaios demonstraram o agravamento dos efeitos da intensa ocupação face à baixa ocupação, com áreas de fundo de vale preservadas. 


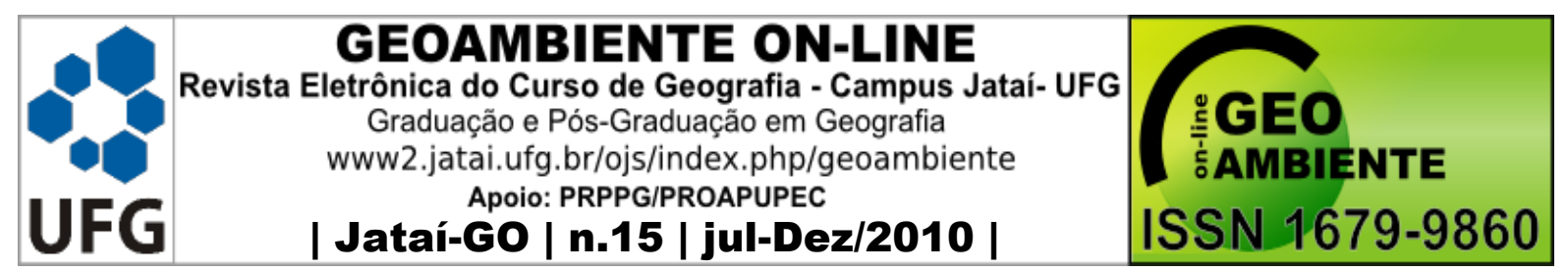

A qualidade do escoamento fluvial no córrego Lagoinha (ponto D) foi pior que a do córrego Mogi, tanto no período seco como no período chuvoso, devido às influências da ocupação urbana.

A área de vegetação mostrou-se eficiente, nos ensaios do dia 5/2 e 3/5/08, em relação à redução da turbidez, dos sólidos suspensos totais, da DBO e do oxigênio dissolvido, exceto no ensaio do dia 1/5/08, onde não foram melhorados seguintes indicadores: turbidez, cobre e OD.

Na microbacia do córrego Mogi, a caracterização química do sedimento carreado pelo escoamento da sarjeta, constatou a presença significativa de cobre, ferro e zinco influenciando na quantidade destes elementos encontrado na água.

As baixas concentrações de poluentes na microbacia do córrego Mogi devem-se ao baixo nível de ocupação e conseqüentemente grande porcentagem de cobertura vegetal $(70 \%)$, ainda, preservada.

\section{5 - Referências}

Associação Brasileira de Normas Técnicas. NBR 7.181: Análise Granulométrica dos Solos. Rio de Janeiro, 1984.

BRASIL. Constituição (1988). Constituição da República Federativa do Brasil. Brasília, DF, Senado Federal, 1988.

Lei Federal no 9.938, de 31 de agosto de 1981. Dispõe sobre a Política Nacional do Meio Ambiente, seus fins e mecanismos de formulação e aplicação, e dá outras providências.

Diário Oficial da União, Brasília, DF, 2 set. 1981. Seção I. Disponível em: <http://migre.me/2pNTx>. Acesso em: 10 mai 2008.

Ministério de Meio Ambiente. Conselho Nacional de meio Ambiente. Resolução CONAMA nº 001 de 1986. Institui a Avaliação de Impacto ambiental. Diário Oficial da União, Brasília, DF. Disponível em: 〈http://migre.me/2pNSf〉. Acesso em: 28 ago. 2007. 


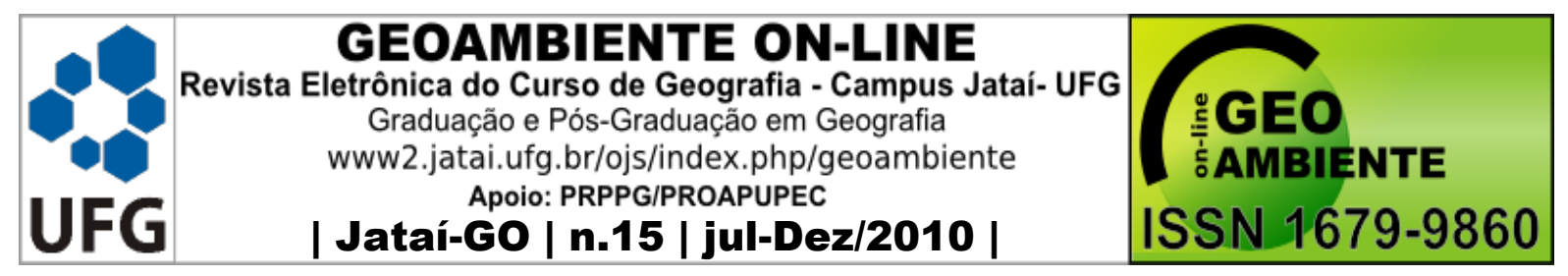

Ministério de Meio Ambiente. Conselho Nacional de meio Ambiente. Resolução CONAMA n 357, de 17 de março de 2005. Dispõe sobre a classificação dos corpos de água e diretrizes ambientais para o seu enquadramento, bem como estabelece as condições e padrões de lançamento de efluentes. Diário Oficial da União, Brasília, DF. Disponível em: <http://migre.me/2pNQI>. Acesso em: 6 dez. 2007.

CETESB - Companhia de Tecnologia de Saneamento Ambiental. Decisão de diretoria $n^{o}$ 195-2005.E, de 23 de novembro de 2005. Dispõe sobre valores orientadores para solos e águas subterrâneas no Estado de São Paulo. Disponível em: <http://migre.me/2pNO0>. Acesso em: 20 out. 2008.

DIAS, Genebaldo Freire. Pegada Ecológica e Sustentabilidade Humana. São Paulo. Gaia, 2002.

GONÇALVES, Flávia de Almeida. Fertilidade e Fitodisponibilidade de metais pesados em solo com resíduos de sucata automobilística. Dissertação de Mestrado em Agricultura Tropical e Subtropical, Instituto Agronômico de Campinas, Campinas, 2008. Disponível em: < http://migre.me/2pNM7>. Acesso em: 11 nov. 2008.

JUSTINO, Eliane Aparecida. Estudo do controle do escoamento superficial com o uso de reservatório de retenção na bacia do córrego Lagoinha, município de Uberlândia - MG. Dissertação de (Mestrado em Engenharia Civil), Universidade Federal de Uberlândia, Uberlândia, 2004. Disponível em: 〈http://www.feciv.ufu.br>. Acesso em: 3 dez. 2007.

THE LIVING EARTH®. Visit the interactive earth. Disponível em: <http://livingearth.com/>. Acesso em: 30 ag. 2008.

TUCCI, C. E. M. Curso de Gestão das inundações urbanas. Porto Alegre: UNESCO Global Water Partnership South America - Associación mundial del agua, 2005. Disponível em: <http://migre.me/2pNCO>. Acesso em: 2 de Janeiro de 2008.

USEPA. Método 6010 B. Inductively Coupled Plasma (ICP) Method. Washington, DC, 1996. UNIVERSIDADE FEDERAL DE UBERLÂNDIA (UFU). Instituto de Geografia. Estação metereológica. Laboratório de climatologia do Instituto de Geografia. IGUFU, 2008. 